\title{
Polyphase extensional basins: interplay between tectonics and sedimentation in the Neogene Siena-Radicofani Basin (Northern Apennines, Italy)
}

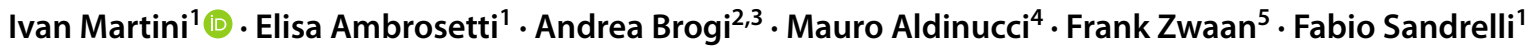

Received: 4 November 2020 / Accepted: 6 April 2021 / Published online: 28 April 2021

(c) The Author(s) 2021

\begin{abstract}
Rift-basins are the shallow effects of lithosphere-scale extensional processes often producing polyphase faulting. Their sedimentary evolution depends on the mutual interplay between tectonics, climate, and eustasy. Estimating the role of each factor is generally a challenging issue. This paper is focused on the tectono-sedimentary evolution of the Neogene Siena-Radicofani Basin, a polyphase structural depression located in the inner Northern Apennines. Since Miocene, this basin developed after prolonged extensional tectonics, first as a bowl-shaped structural depression, later reorganized into a half-graben structure due to the activation of high-angle normal faults in the Zanclean. At that time the basin contained coeval continental and marine settings controlled by the normal faulting that caused the development of local coarse-grained depositional systems. These were investigated to: (i) discriminate between the influences of tectonics and climate on sedimentation patterns, and (ii) provide detailed time constraints on fault activity. The analysed successions were deposited in an interval between 5.08 and 4.52 Ma, when a climate-induced highstand phase occurred throughout the Mediterranean. However, evidence of local relative sea-level drops is registered in the sedimentary record, often associated with increased accommodation space and sediment supply. Such base-level fluctuations are not connected to climate changes, suggesting that the faults generally control sedimentation along the basin margins.
\end{abstract}

Keywords Marine-continental sedimentation $\cdot$ Extensional tectonics $\cdot$ Coarse-grained deposits $\cdot$ Inner Northern Apennines $\cdot$ Siena-Radicofani Basin

\section{Introduction}

One of the main effects of lithosphere extension is the development of structural depressions (i.e., sedimentary basins) that form due to the activity of normal faults (McKenzie

Ivan Martini

ivan.martini@unisi.it

1 Department of Environment, Earth and Physical Sciences, University of Siena, via Laterina 8, 53100 Siena, Italy

2 Department of Earth and Geoenvironmental Sciences, University of Bari “Aldo Moro”, Via Orabona 4, 70125 Bari, Italy

3 Institute of Geosciences and Earth Resources, IGG-CNR, Via Moruzzi 1, Pisa, Italy

4 Vår Energi, Vestre Svanholmen 1, 4313 Sandnes, Norway

5 Institute of Geological Sciences, University of Bern, Baltzerstrasse 1+3, 3012 Bern, Switzerland
1978; Lister and Davis 1989; Gibbs 1990). Within the context of extensional tectonics, hangingwall and supradetachment basins are structural depressions related to extensional detachments (i.e., low angle normal faults, hereafter LANFs) controlling the progressive asymmetric growth of the basins and their syn-tectonic sedimentary infilling (Mack et al. 2003; Brogi and Liotta, 2008 and references therein). Hangingwall and supradetachment basins represent end-members of extensional basins, which are typical of highly-extended terrains (Friedman and Burbank 1995), where most of the sedimentary infill overlies the detachment (i.e., supradetachment) or detachment-roof (i.e., hangingwall basins). These basins are different from those bounded by high-angle normal faults (hereafter HANFs) and typified by a lower amount of extension (Friedman and Burbank 1995). These two end-member basin types can be found coexisting in the same extensional settings, typically resulting from decreasing strain rates combined with the progressive exhumation 
of the deeper structural levels (Davis and Coney 1979; Lister et al. 1984; Jolivet et al. 1994; Booth-Rea et al. 2004).

LANFs typically predate HANFs in response to the crustal heating and weakening, uplift, and exhumation followed by the reduction of strain rate and thermal re-equilibration, as described in areas of the extended continental crust due to orogenic collapse (Rosenbaum et al. 2005 with references therein), such as the case of the inner Northern Apennines (Carmignani et al. 1994; Dallmeyer and Liotta 1998; Brogi et al. 2005). However, the opposite is also observed, i.e., high-angle normal faulting followed by detachment faulting (Froitzheim and Manatschal 1996).

Different types of extensional basins develop different stratigraphic architectures. Although several papers describe the stratigraphic variability of graben and half-graben (namely basins controlled by HANFs: e.g., Gawthorpe and Leader 2000; Martins-Neto and Catuneanu 2010), few studies address the stratigraphic architecture of hangingwall and supradetachment basins later segmented by HANFs (e.g., Wernicke and Burchfiel 1982; Davis and Lister 1988; Friedmann and Burbank 1995).

The Siena-Radicofani Basin (inner Northern Apennines, Italy) is an excellent natural laboratory to investigate the tectonic impact on continental and marine sedimentation during its polyphase extension history. Specifically, the basin developed as a hangingwall basin since the Middle Miocene (Brogi 2011). Starting from the early Pliocene, the basin turned into a half graben due to the activation of a basinscale HANF system along its eastern margin (Pascucci et al. 2007; Brogi 2008).

This paper aims at: (i) defining the timing of the LANF to HANF transition in the Siena-Radicofani Basin; (ii) assessing the change of sedimentation patterns resulting from the activation of HANFs, and (iii) providing criteria to discriminate between tectonic $v s$ climate control in the developments of marginal/paralic clastic successions. For this purpose, we reconstructed the tectonic evolution of the basin through the interpretation of 2D reflection seismic lines and structural analysis of key areas. Subsequently, we investigated five continental to open-marine successions and combined stratigraphic and sedimentological data with biostratigraphic analysis and palaeosoil information. Finally, the resulting stratigraphic dataset is linked to the previously established tectonic framework of the study area.

\section{Geological setting of the Siena-Radicofani Basin}

The Siena-Radicofani Basin is an elongated, NNW-SSE trending structural depression of southern Tuscany (Fig. 1a, b) that consists of two sectors, named the Siena and Radicofani sub-basins, to the north and south, respectively. The
Siena-Radicofani Basin developed in the hinterland of the Northern Apennines (Fig. 1a, cf. Martini and Sagri 1993) and its infill provides one of the best records of the post-collisional deposition in this sector of Apennines (Fig. 2). The area was affected by lithosphere-scale extensional tectonics since the Early to Middle Miocene (Carmignani et al. 1995; Jolivet et al. 1998; Liotta et al. 1998; Barchi 2010). Extension caused the thinning of the previously overthickened crust (Calcagnile and Panza 1981; Locardi and Nicolich 1992) and gave rise to widespread magmatism (Serri et al. 1993; Peccerillo 2003; Poli et al. 2002; Dini et al. 2005).

The evolution of the Siena-Radicofani Basin and other basins of the inner Northern Apennines is the subject of ongoing scientific debate. These basins have either been interpreted as grabens and half-grabens (Carmignani and Kligfield 1990; Martini and Sagri 1993; Pascucci et al. 1999, 2006, 2007; Carmignani et al. 2001) or thrust-top basins developed in a polyphase compressional setting active until Quaternary times (Boccaletti and Sani 1998; Bonini 1999; Finetti et al. 2001; Bonini and Sani 2002). This topic is discussed in recent papers to which the reader is addressed for more details (Brogi et al. 2005; Brogi 2008; Brogi and Liotta 2008; Liotta and Brogi 2020). Brogi (2011) linked the earliest (i.e., Serravallian-Late Messinian) evolution of the Siena-Radicofani Basin (i.e., its northern sector, the Siena sub-Basin) to the development of a hanging-wall basin associated with extensional detachments that formed a bowlshaped structural depression. This structural depression was later dissected by late Zanclean-early Piacenzian HANFs (Brogi 2011, 2020) which, however, only slightly modified the original basin architecture. Specifically, the eastern margin of the Siena-Radicofani Basin is bounded by a regional NNW-trending high-angle normal fault system discontinuously exposed for several kilometres (Figs. 1, 3, 4a). Traditionally, this structure is referred to as the "Rapolano Fault" in the northern part of the basin, and the "Cetona Fault" in its southern part (Passerini 1964; Liotta, 1996). This fault system consists of major and minor west-dipping HANFs characterised by cumulative displacement of about $1.5-2 \mathrm{~km}$ as estimated at its southern end (Liotta 1996; Pascucci et al. 2006, 2007; Fig. 3), and of about $400 \mathrm{~m}$ in the northern part (Brogi 2011). The characteristics of the Neogene infill are different in the northern (i.e., Siena) and southern (i.e., Radicofani) basins. For this reason, past studies generally considered this structural depression as consisting of two distinct basins, the northern Siena Basin and the southern Radicofani Basin, with an intervening subtle structural high (i.e., the "Pienza high", see Figs. 1,2) that influenced at least the Pliocene stratigraphic evolution.

In this study, we instead present the Siena-Radicofani Basin as a continuous basin; we show that the Siena and Radicofani sub-basins are genetically related and share most of the tectono-stratigraphic events affecting the area. 


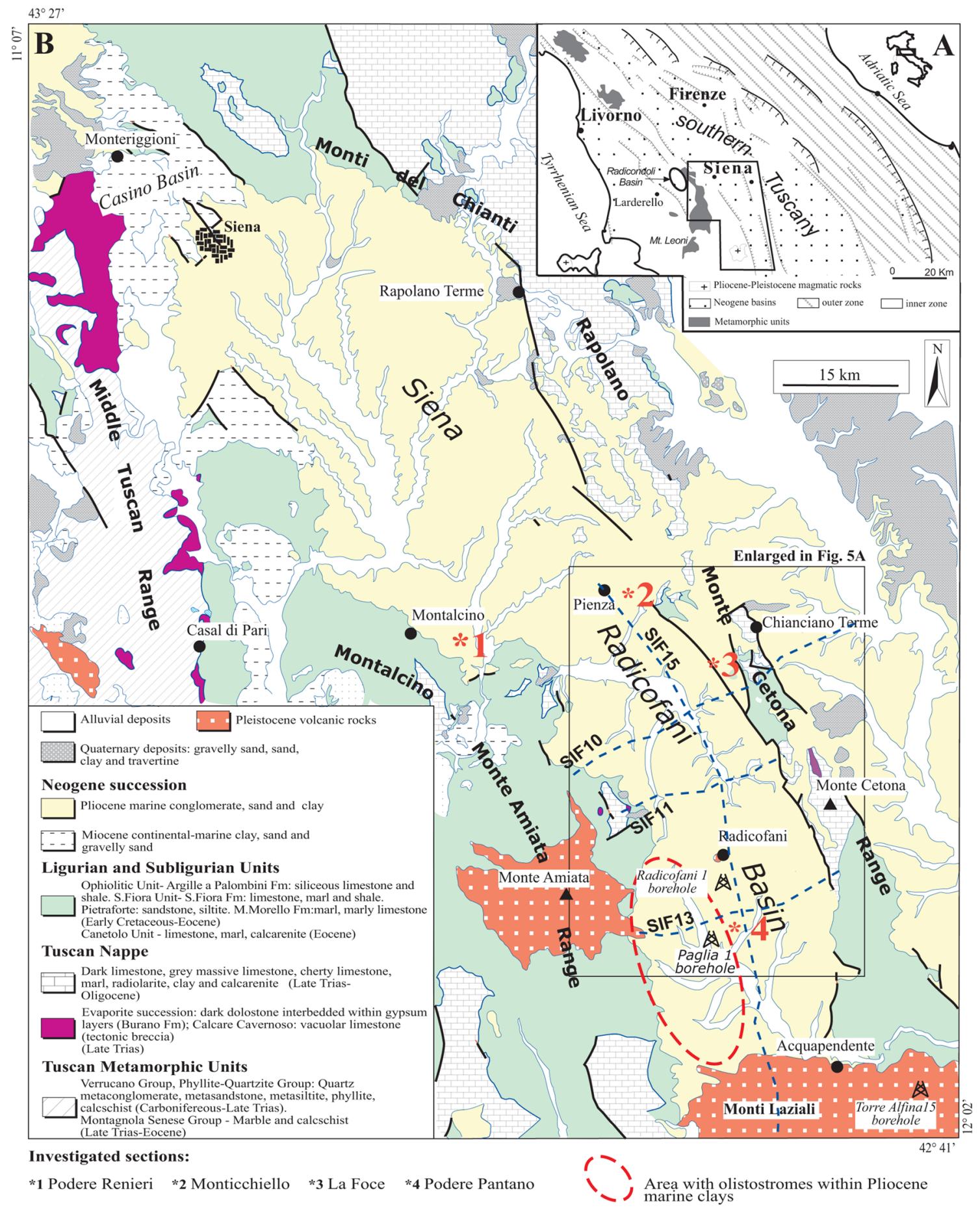

Fig. 1 a Tectonic sketch of the Northern Apennines. b Geological map of the Siena-Radicofani Basin, with location of investigated sections and traces of seismic profiles (modified from Brogi 2011)

In this view, the "Pienza high" never represented a major morpho-structural feature compartmentalising the evolution of the sub-basins. In addition, the flooding of the "Pienza high" during the Zanclean established marine communication between northern and southern sectors of the SienaRadicofani Basin.

\section{Neogene-Pleistocene sedimentation in the Siena-Radicofani Basin}

Neogene sedimentation in the Siena-Radicofani Basin started in the late Serravallian-Messinian with the deposition of continental to shallow marine sediments. These sediments 


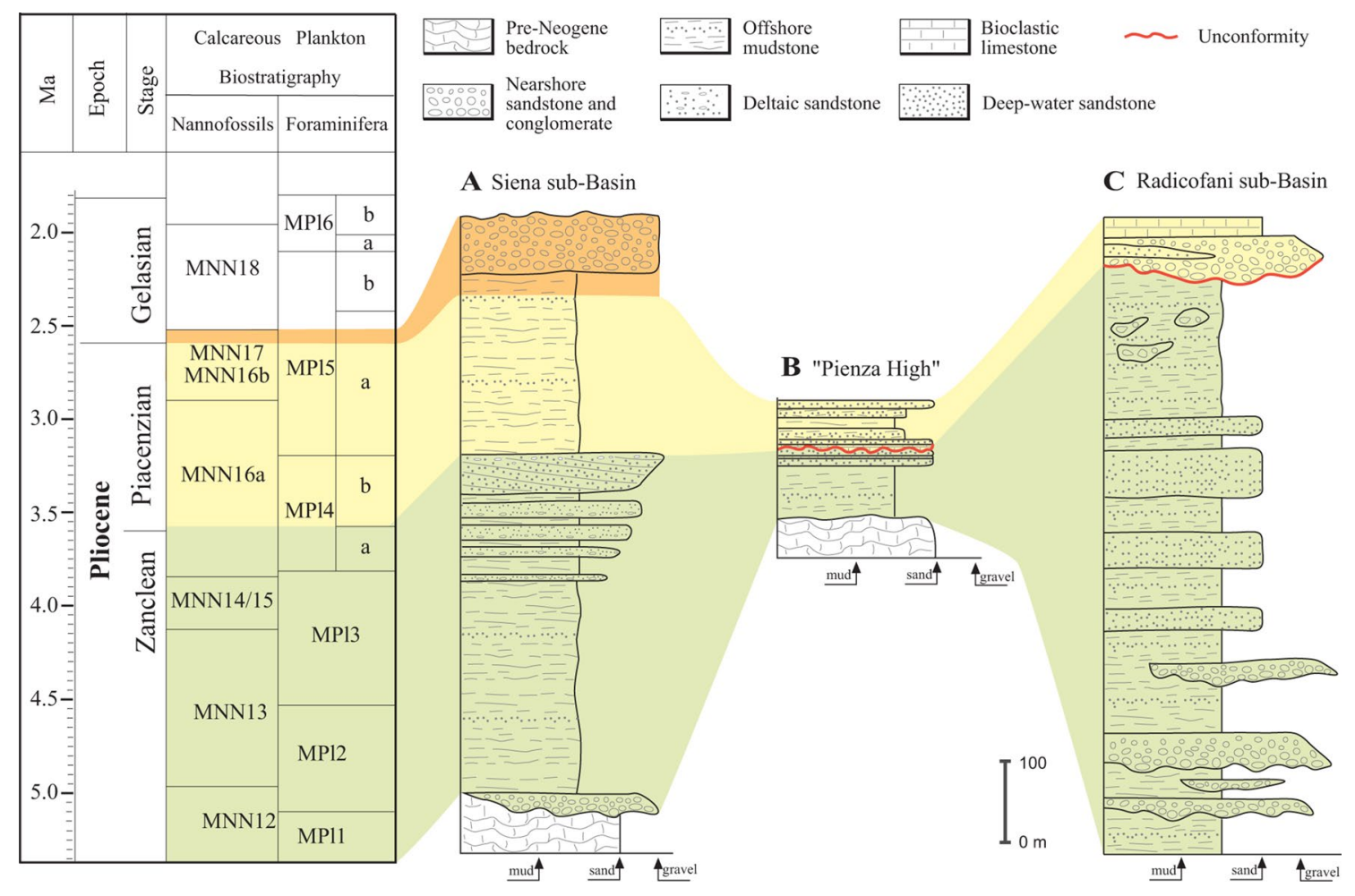

Fig. 2 Synthetic stratigraphic columns of the Pliocene sedimentary infill in various sectors of the Siena-Radicofani Basin and their bioand chrono-stratigraphic correlation (data for the Siena sub-Basin derived from Bossio et al. 1992, 1993; Martini and Sandrelli, 2015; Martini et al. 2015, 2017; data for the Radicofani sub-Basin derived from Liotta and Salvatorini 1994) are exposed in small marginal areas in the northern part of the Siena sub-Basin (Lazzarotto and Sandrelli 1977; Bossio et al. 2002) and possibly imaged in some 2D seismic lines in the Radicofani sub-Basin as well (Bonini and Sani 2002; Brogi 2011). Pliocene sedimentation was characterised by a basin-scale marine transgression mainly recorded by offshore fine-grained sediments and marginal paralic, locally coarse-grained, deposits (Fig. 2). Specifically, Pliocene sedimentation was different in the two sub-basins, with its features described below and summarised in Fig. 2:

(I) In the Siena sub-Basin Pliocene deposits reach a maximum thickness of about $600 \mathrm{~m}$ (Bonini and Sani 2002; Brogi 2011) and unconformably overlie both the Miocene continental deposits and the basin substratum (Costantini et al. 1982). Pliocene deposits consist mostly of marine sediments, even if alluvial sediments were deposited close to the basin margins (Bossio et al. 1992, 1993; Aldinucci et al. 2007; Martini et al. 2011, 2013; Arragoni et al. 2012). Pliocene marine sedimentation started in the early Zanclean (Bossio et al. 1992; Riforgiato et al. 2005) and lasted until the upper Piacenzian/ lower Gelasian (Martini et al. 2016; Martini and Aldinucci 2017) due to regional uplift (Marinelli
1975). Finally, in some sectors of the sub-basin, Pliocene sediments were unconformably overlain by fluvio-lacustrine Pleistocene gravel, sand, clay and/or Pleistocene travertine (Aldinucci et al. 2007; Brogi 2004; Bianchi et al. 2013);

(II) In the Radicofani sub-Basin Pliocene deposits are thicker, exceeding $1 \mathrm{~km}$ in the depocentral part of the basin, and unconformably overlie the Miocene continental deposits (Liotta 1996; Bonini and Sani 2002; Brogi 2008; Marroni et al. 2015). Two distinct depositional "cycles" have traditionally been described for the Pliocene succession (Iaccarino et al. 1994; Liotta and Salvatorini 1994; Pascucci 2004; Ghinassi and Lazzarotto 2005). The older "cycle" is characterized by siliciclastic sediments (sandstone, mudstone, and claystone passing basinward to offshore mudstone with interbedded turbidites) and extends from the base to the top of the Zanclean (MP11 to MP14a biozones of the zonal scheme proposed by Iaccarino et al. 2007 and references therein). The younger cycle is mainly composed of Amphistegina limestone and nearshore sandstone deposited during the Piacenzian (MP14bMP15a, cf. Iaccarino et al. 1994) and unconformably overlies both the older Pliocene sediments and 
the pre-Neogene bedrock. Piacenzian deposits only crop out close to the eastern basin margin. Finally, Pliocene sediments were intruded and covered by magmatic rocks, presently preserved in the Radicofani neck (trachybasalt, olivine-latite and olivinetrachytic scoria dated at about 1.3 Ma, D’Orazio et al. 1991, 1994, Fig. 1).

\section{Methods and terminology}

This study is based on the integration of different data sets, including: (i) reflection seismic lines and borehole data; (ii) structural and kinematic data; and (iii) stratigraphic and sedimentological analyses. Seismic and structural data were collected in the Radicofani sub-Basin to integrate them with the dataset presented from the Siena sub-Basin by Brogi (2011).

Four seismic profiles acquired in the $80 \mathrm{~s}$ by AGIP-FINA for oil exploration, using vibroseis energy sources, have been analysed. The applied conventional processing sequence provided by Mariani \& Prato (1988) allows us to image the basin and its substratum down to $3 \mathrm{~s}$ two-way travel time (TWT), with a datum plane at $200 \mathrm{~m}$ above sea level. Well data from 6 boreholes have been used to calibrate the seismic interpretation (cf. Bonini and Sani 2002; Brogi 2008; Brogi and Fabbrini 2009).

Structural and kinematic data were collected along the Cetona Fault (HANF) that together with its northern continuation (the so-called "Rapolano Fault", for which structural data was presented in Brogi 2011) is the master fault of the Siena-Radicofani Basin (Fig. 1).

Stratigraphic and sedimentological data have been collected in five key localities (Fig. 1), which are described following the sedimentological terminology of Harms et al. $(1975,1982)$ and Collinson et al. (2006). These new data are integrated with published data regarding the bio-chronostratigraphic attribution of the investigated successions. Data are standardised according to the zonal schemes of Cita (1975), Raffi and Rio (1979), Rio et al. (1990), Lourens et al. (2004) and Iaccarino et al. (2007).

\section{Seismic interpretation}

Seismic profiles through the Radicofani sub-Basin, SIF 10, 11, and 13 (all striking SW-NE, i.e., perpendicular to the basin axis), and SIF 15 (oriented NW-SE along the basin axis, see Fig. 3 and Fig. 1b for their location) have been interpreted to reconstruct its architectural features. Available borehole logs (Fig. 3) allow the calibration of seismic facies and the main seismic markers.
All seismic profiles show widespread reflectivity in the upper part, characterized by high contrast in acoustic impedance (Fig. 3). The base of the basin (i.e., boundary between pre-Neogene substratum and Neogene deposits) is highlighted by a rather continuous seismic marker consisting of a high amplitude and high-frequency reflection (Fig. 3, SIF13). In contrast, the basin substratum (seismic units C-E in Fig. 3) is characterized by attenuated reflectivity due to the absorption of energy by the overlying less consolidated sediments.

We focus on the description of seismic features of Neogene seismic units (A and B); the reader is addressed to Brogi and Fabbrini (2009) for the description of the pre-Neogene seismic units (C-E). Concerning the Neogene filling sediments, two seismic units (A and B) delimited by angular unconformities have been recognized. Borehole data allow us to correlate seismic unit B with Miocene deposits and seismic unit A with Pliocene deposits. The stratigraphically lower seismic unit B is only imaged in seismic profiles SIF11, SIF13 and SIF15 (Fig. 3). The unit is characterized by local, well-organized and sub-parallel, short reflections with moderate amplitude, and by quasi-transparent patterns. Reflections are sub-parallel to the base of the basin, onlapping toward both west and east, defining an asymmetric synform. Seismic unit B unconformably overlies seismic unit $\mathrm{A}$; the angular unconformity is marked by a continuous high-amplitude reflection, locally assuming bright-spot characteristics (Fig. 3).

Seismic unit A overlies both unit B and the basin substratum (Fig. 3) and is characterized by high amplitude, wellmarked, parallel, and continuous reflections, between which quasi-transparent patterns are locally sandwiched. The highamplitude reflection at the base of unit A shows a dome shape centred in the central part of seismic profiles SIF11 and SIF13 (Fig. 3). In contrast, this feature is not recognisable in the SIF10 profile, suggesting its progressive smoothing toward the north. This is imaged by the NW-SE profile SIF15, in which the base of the seismic unit A unconformably overlies the basin substratum with sub-horizontal internal reflections. The reflections become gently east-dipping in the eastern part of the basin (SIF10, SIF11 and SIF13 profiles, Fig. 3), downlapping the basin substratum and forming a broad asymmetric bowl-shape reflection, particularly evident in profiles SIF10, SIF11 and SIF12 (Fig. 3). In the easternmost part of these profiles, the gently inclined reflections are truncated by a transparent pattern corresponding to the basin substratum, thus indicating the westward dipping "Cetona Fault" system. It appears to be composed of different coalescing fault segments displacing the base of seismic unit A with vertical offset $<0.3 \mathrm{~s}$ TWT (Fig. 3). In the western part of the basin, the reflections become gently west-dipping (SIF11, Fig. 3), and downlap the basin substratum. Laterally, the gently inclined reflections are truncated by different seismic facies typical of 

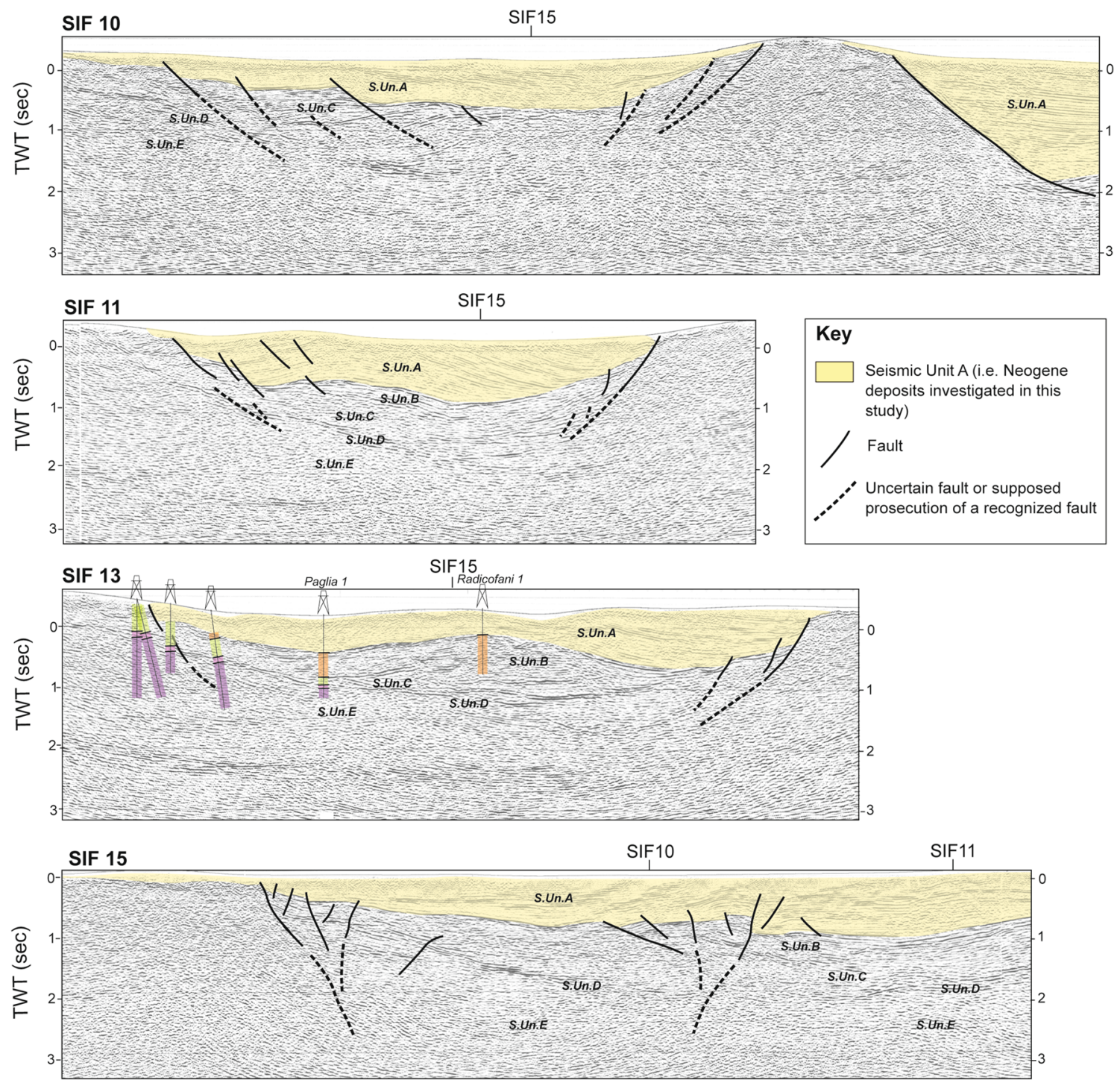

"Paglia " borehole

"Radicofani 1" borehole

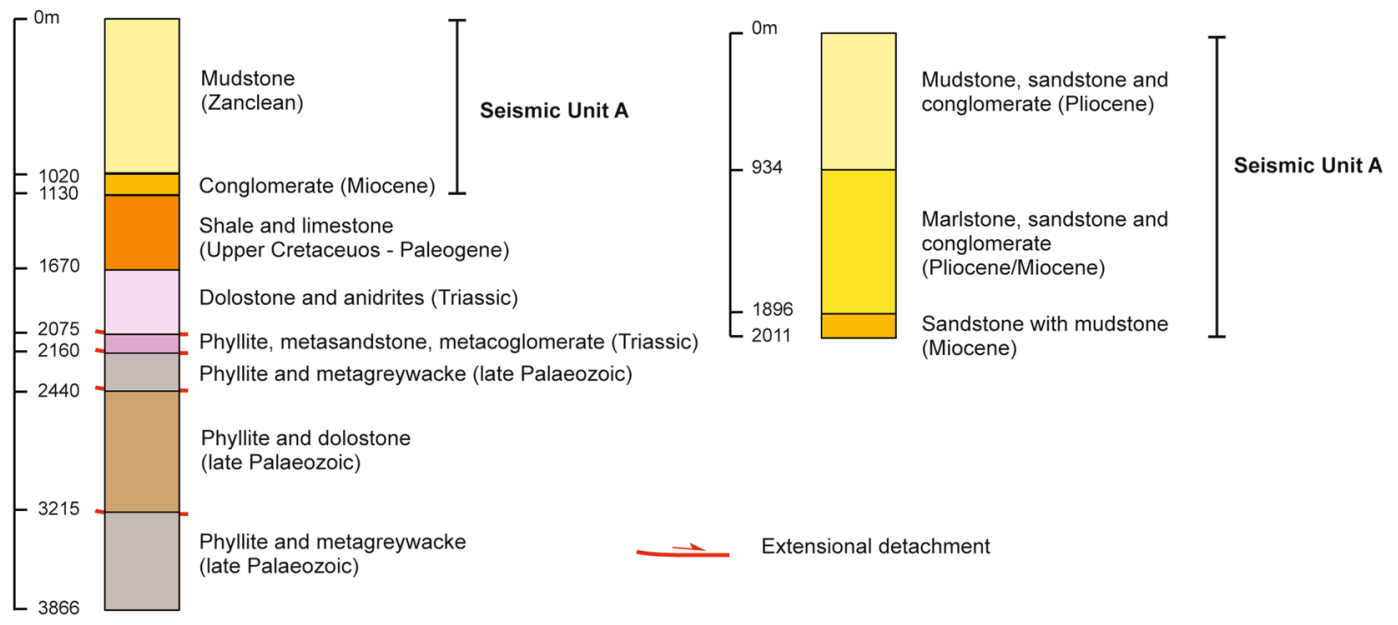

Fig. 3 Migrated reflection seismic profiles (seismic lines are from Bonini and Sani 2002 and Pascucci et al. 2007) and stratigraphy of the two most important calibration boreholes. The line drawings show the geological interpretation of the main faults and filling sediments. TWT: two-way travel time 
the basin substratum, indicating westward-dipping normal fault segments with a total offset $<0.4 \mathrm{~s}$ TWT.

Seismic profile SIF15 highlights two main fault zones, characterized by fault arrays that are interpreted as positive flower structures, therefore indicating strike- to oblique-slip kinematics. Faults show normal and minor reverse offsets up to $0.2 \mathrm{~s}$ TWT of the basin substratum and affect all the overlying seismic units. The kinematics of these faults have been defined at the surface, where some of these segments are exposed. These data are reported in the following paragraph.

\section{Structural and kinematic data}

As previously stated, the Siena-Radicofani Basin developed as a hanging-wall basin since the Serravallian-Late Messinian; its architecture was modified by a HANF system during Zanclean-Piacenzian (Brogi 2011). HANFs produced a half-graben structure, with the master fault system located in the eastern margin of the basin (i.e., Rapolano Fault, to the north, and the Cetona Fault, to the south). Minor HANFs
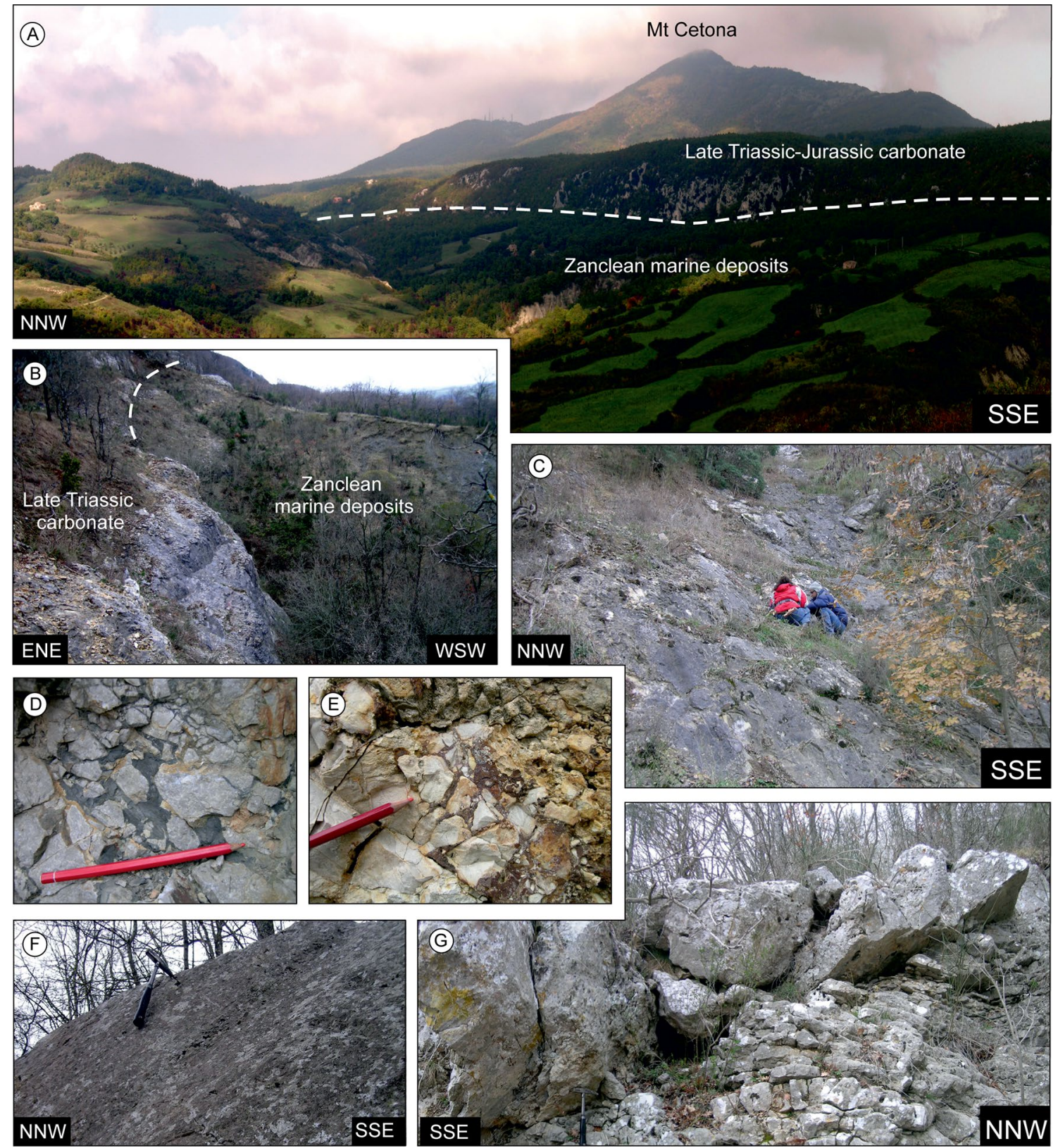

Fig. 4 a Panoramic view of the Cetona normal fault scarp; b detail of the Cetona Fault scarp separating the Triassic "Calcari a Rhaetavicula contorta" Fm from the clastic Pliocene sediments; $\mathbf{c}$ detail of the main fault surface; $(\mathbf{d}, \mathbf{e})$ tectonic breccia cemented by clay (d) and Fe-hydroxides (e) forming the main cataclasite level; (f, $\mathbf{g}$ ) minor faults affecting the footwall of the Cetona Fault 
also occur in the western margin of the Basin (Costantini et al. 1982) (Figs. 1, 3).

In this paragraph, we present structural and kinematic data (i) from the Cetona Fault, and (ii) from NE-striking faults cutting the Cetona Fault that are interpreted as part of a transfer zone active during the basin development (see Liotta, 1991; Brogi et al. 2010a, b, 2014, 2020 for the SienaRadicofani Basin; Dini et al. 2008; Liotta et al. 2015; Liotta and Brogi, 2020 for a broader overview on the inner Northern Apennines).

The Cetona Fault, NNW-striking and steeply dipping toward WSW, juxtaposes the Neogene deposits filling the basin with the Jurassic carbonate succession (Figs. 1, 3, $4 a-c)$. It is characterised by a decametres-thick fault zone with a fault core consisting of a meter-thick cataclasite made up of discontinuous breccia formed by $\mathrm{mm}$ - to dm-sized elements, dispersed within a clayey matrix mainly composed of Pliocene marine sandy clay (Fig. 4d-e). The damage zone, well developed in the footwall, consists of about 40-50 m of fractured carbonate beds belonging to the Late Triassic Calcare a Rhaetavicula contorta Fm or Early Jurassic Calcare Massiccio Fm (Fig. 1). Fractures (comprising mode-I joints, deformation bands, and slip surfaces) are spaced from 1 to 20 fractures per metre and are aligned parallel to the fault plane. En-echelon fractures are mainly developed in the hanging wall where minor normal faults (Figs. 4f-g), characterized by metre-scale displacements, are close to the principal slip surface. The geometry and kinematics of the minor faults are compatible with the master fault evolution.

Kinematic indicators consist of slickenlines, calcite slickenfibres, lunate structures, chatter marks and grooves. The kinematic analyses carried out on more than 50 structural stations on both main and minor faults indicate that the fault system delimiting the eastern side of the Radiconfani subBasin was mainly characterized by a dominant down-dip movement coupled with a modest strike-slip one (obliqueslip transtensional kinematics, Fig. 5). Minor faults showing similar geometric and kinematic features also affected the Zanclean sediments, but they are buried by Piacenzian calcarenite (Liotta 1996; Pascucci et al. 2007).

Faults belonging to the transfer fault system interrupt, in several parts, the continuity of the NNW-trending Cetona fault system (Fig. 5a). These structures are NE-striking and define brittle shear zones up to $1 \mathrm{~km}$ wide, formed by fault segments that are often anastomosed and characterized by almost strike-slip to normal movements. The fault segments affect Mesozoic carbonate rocks and are characterized by a thin $(c a .5-10 \mathrm{~cm})$ core zone. Their damage zones range from 1 to $5 \mathrm{~m}$ in width and are characterized by fractured rock masses with $\mathrm{Ca}$ and $\mathrm{Ca}-\mathrm{Fe}$ carbonate and $\mathrm{Fe}$-hydroxide veins.

Kinematic indicators, consisting of mechanical striations, calcite and Fe-hydroxide fibres, and minor fractures within the damage zones, indicate left-lateral kinematics (Fig. 5b). NE-striking faults are often arranged in overstepping segments that form releasing step-over zones up to $1.5 \mathrm{~km}$ long and $2 \mathrm{~km}$ wide (Fig. 5b). These areas correspond to localised structural depressions interpreted as negative flower structures (see Fig. 5b). In area 2 (Fig. 5a) the exposed NE-striking faults correspond to those identified in the seismic profile SIF15 (Fig. 3). Outcrops show coexisting transpressional and transtensional faults, with a dominant left-lateral strike-slip component (Fig. 6). Horizontal off-sets cannot be defined, whereas, in some cases, the vertical ones exceed $20 \mathrm{~m}$. In some cases, fault segments with transpressive kinematics define positive flower-like structures giving rise to gentle folds affecting the Zanclean marine sediments (Fig. 6).

The age of the NE-striking faults defining the transfer zones can be placed between Pliocene and late Pleistocene, or even younger, on the basis of their role in favoring Pleistocene travertine deposition (cf, Brogi et al. 2012) and in controlling the Pliocene sedimentation (Pascucci et al. 2007). Nevertheless, an older age (i.e., Middle-Late Miocene) cannot be ruled out on the basis of regional considerations (see. Liotta et al. 2015; Zucchi, 2020).

\section{The investigated successions}

The stratigraphic and sedimentological features of five successions are described below (see Figs. 7, 8, 9, 10). All these successions were deposited in the Zanclean and are characterized by the occurrence of thick coarse-grained deposits that record deposition in different sedimentary environments (Fig. 2).

\section{Podere Renieri succession}

\section{Stratigraphy and sedimentology}

The Podere Renieri succession crops out on the western margin of the Siena sub-Basin (Fig. 1), is about $180 \mathrm{~m}$ thick and comprises three intervals (PR_1 to PR_3, Fig. 7a), here described in stratigraphic order. Interval PR_1 ( $100 \mathrm{~m}$ thick) is fully marine and unconformably overlies the pre-Neogene substratum (Fig. 7a). The interval starts with wave-winnowed lag deposits passing upward to fossiliferous marine sandy mudstones indicative of an offshore transition setting. At the top of the interval, mudstones are abruptly overlain by clinostratified fine- to medium-grained sandstones (Fig. 7B), which at places contain lens-shaped conglomerate bodies. These features suggest a deposition in a marine shoal-water delta environment, in which lens-shaped conglomerates can be 

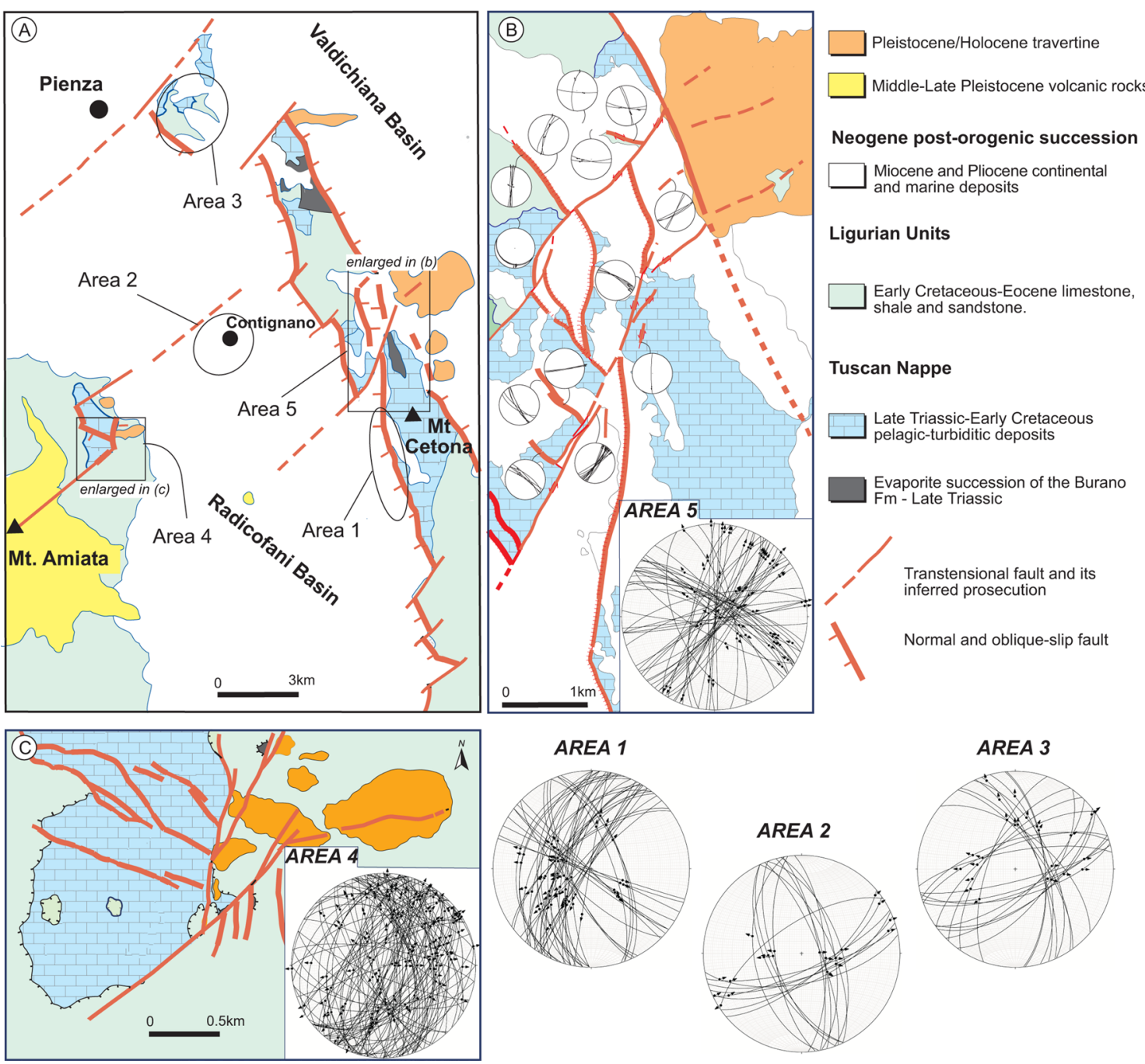

Fig. 5 a Tectonic sketch-map of the Radicofani sub-Basin showing the main structures and the areas where the structural and kinematics analyses have been carried out. b, $\mathbf{c}$ details of the tectonic setting

interpreted as distributary channels (sensu Ambrosetti et al. 2017).

Interval PR_2 ( $60 \mathrm{~m}$ thick $)$ is fully continental and starts with lacustrine grey sandy mudstone containing root traces, ostracods and characeae oogons (Bossio et al. 1992), indicative of a shallow lacustrine environment (Fig. 7a). These lacustrine sediments grade upwards to alluvial fan deposits that are composed of conglomerates, sandy mudstones and pebbly sandstones arranged in a coarsening- to fining-upward succession (Fig. 7c). The alluvial fan deposits display evidence of pedogenetic processes of which a detailed description is provided by Costantini and Priori (2007). These authors recognized that the most distinctive paleosols contained plinthite, which is typical of hot and humid climates (Costantini and Priori 2007 and references therein). of some analysed areas. Stereographic diagrams (lower hemisphere, Schmidt diagram) showing the main kinematics data are also illustrated

Finally, interval PR_3 ( $15 \mathrm{~m}$ thick) starts with pebbly conglomerate alternating with dark-grey mudstone units, rich in organic matter and containing fauna indicative of lagoonal settings (Figs. 7a-c, cf. Bossio et al. 1992). The lagoonal deposits are overlain by shallow marine silty sandstone containing mollusc fragments passing upward to offshore mudstone.

\section{Depositional age}

Bio-chronostratigraphic analysis performed by Bossio et al. (1992) indicates that the deposition of interval PR_1 occurred in the Zanclean. The deposition started at the base of the MP11 biozone and persisted until the MP12 biozone. The deposits of interval PR 2 do not contain bio-chronostratigraphic indicators. However, the base of interval PR_3 
Fig. 6 a Transpressive mesoscopic faults affecting Zanclean sandstone and conglomerate near Contignano (area 2 in Fig. 5). b, c photographs illustrating the kinematic indicators consisting of mechanical striation and suggesting a dominant strike-slip movement. d Southeast-dipping sediments in the flank of the flower structure recognised in the area 2 (see Figs. 2 and 5 for location). e, f mesoscopic normal faults coexisting with the strike-slip and their transpressive counterparts in the area 2 (see Fig. 5 for location)
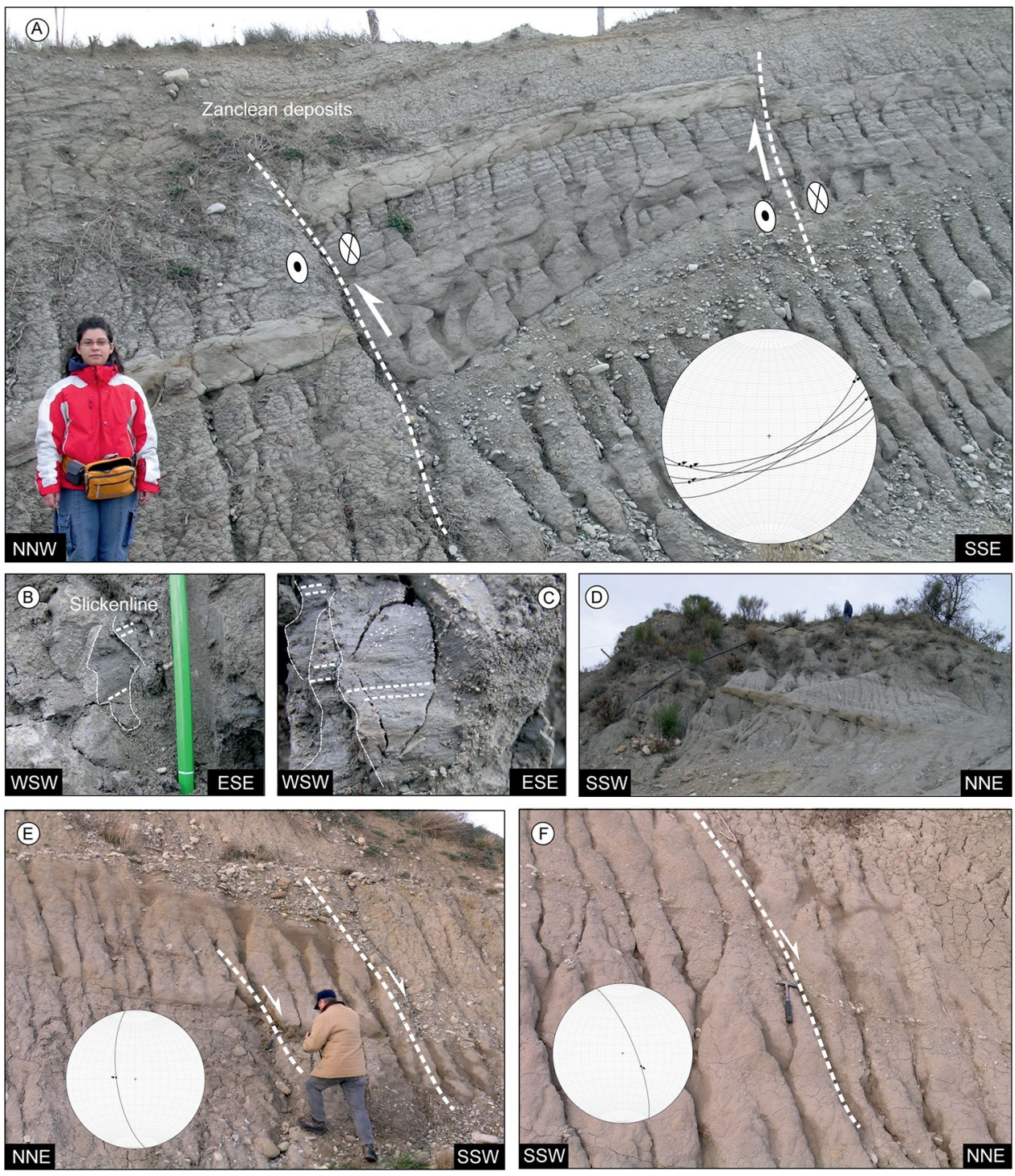

is well constrained to the MPl3 biozone (Bossio et al. 1992). Therefore, the continental interval PR_2 was deposited in the Zanclean, and more specifically in the MPI2 and MPl3 biozones, i.e., between 4.8 and 4.1 Ma.

\section{Monticchiello succession}

\section{Stratigraphy and sedimentology}

The Monticchiello succession was deposited in fully marine settings (Martini et al. 2017) and is subdivided in three intervals (MO_1 to MO_3 in stratigraphic order, Fig. 8b). Interval MO_1 shows at the base gently inclined (up to $7-8^{\circ}$ ) shoal-water delta mouth-bar deposits (sandstones with minor conglomerates), passing basinward to sub-horizontal prodelta fine-grained sediments (Fig. 8a, b). These deposits are abruptly overlain by coarse-grained and seaward inclined conglomerates belonging to interval
MO_2. This interval is about $65 \mathrm{~m}$ thick and displays a vertical progressive increase in inclination (up to about $30^{\circ}$ ), basinward passing into sub-horizontal alternation of mudstone, sandstone and conglomerate (Fig. 8a, b, c). According to Martini et al. (2017), the deposits of interval MO_2 document a Gilbert-type delta environment (Gilbert 1885), in which the inclined bedsets represent the delta foreset, whereas underlying sub-horizontal bedsets correspond to the bottomset. Finally, gently inclined to subhorizontal poorly sorted shoal-water delta sandstone (up to $30 \mathrm{~m}$ thick) overlies both foreset and bottomset deposits (Figs. 8a, b), through a sharp surface marked by a gravel lag. These deposits constitute interval MO_3. According to Martini et al. (2017), the bounding surface between intervals MO_2 and MO_3 records the combination of a relative sea-level fall and a subsequent transgression. 


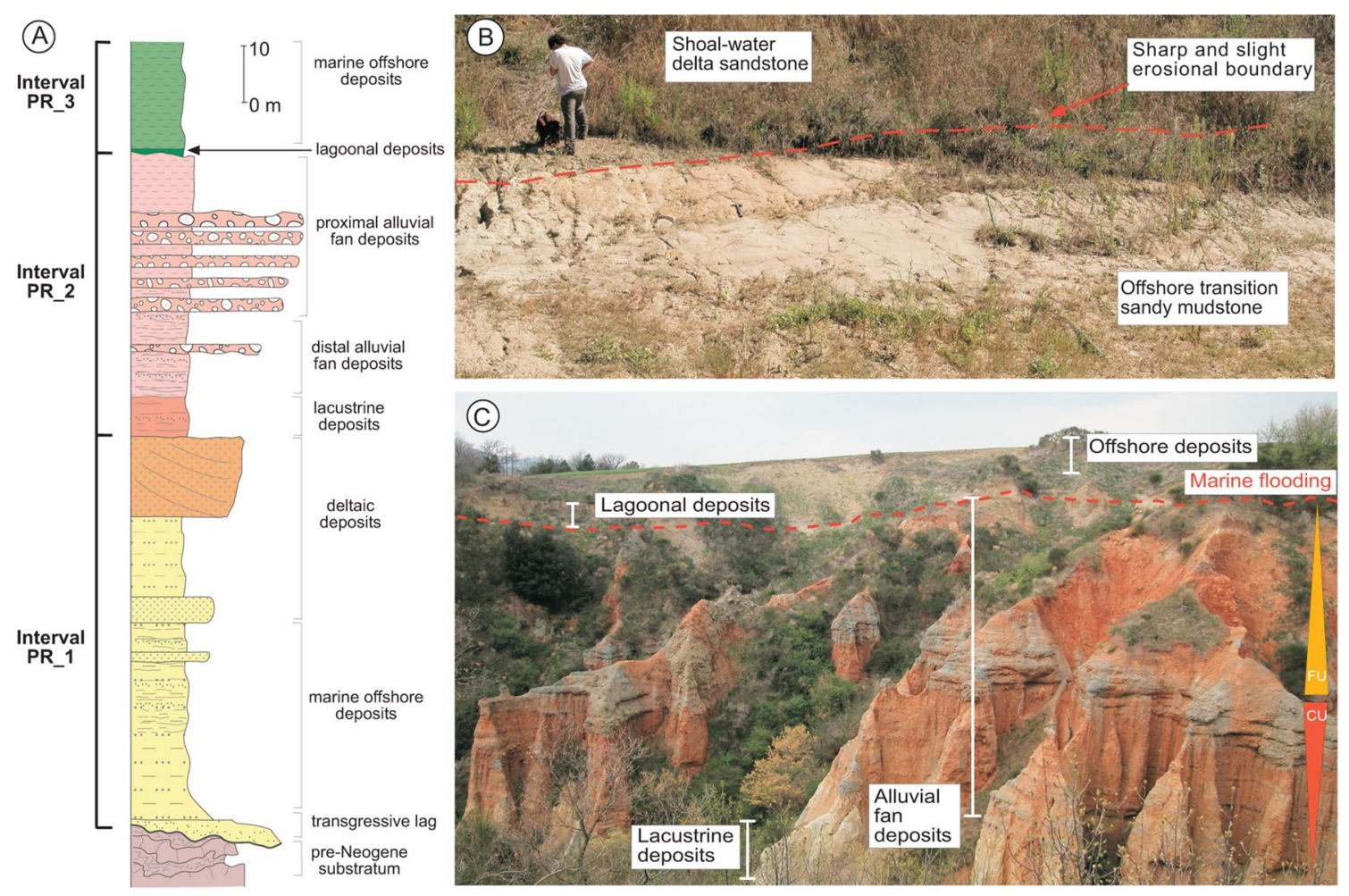

Fig. 7 a Stratigraphic log of the sedimentary succession exposed at Podere Renieri (PR 1-3). b Sharp and slight erosional boundary separating offshore transition deposits from shoal-water deltaic sandstone. c Panoramic view of the continental succession exposed at Podere

\section{Depositional age}

Micropaleontological data indicate that the Gilbert-type sediments were deposited in the Zanclean, and more in particular in the MNN14/15 calcareous nannofossils biozone (Martini et al. 2017), i.e., in a time-interval between 4.13 and 3.85 Ma. The uppermost shoal-water delta deposits are lateral equivalent to deposits exposed in nearby areas and belong to the upper part of the Zanclean (MPI4a biozone, Marini 2001).

\section{La Foce succession}

\section{Stratigraphy and sedimentology}

The succession exposed at "La Foce" mainly consists of coarse-grained conglomerate and gravelly sandstone. These deposits form an extended wedge (Fig. 9a), which is locally downfaulted and recognizable in seismic lines (Costantini and Dringoli 2003; Pascucci et al. 2006, see also seismic line SIF10 in Fig. 3) passing laterally to offshore marine deposits (cf. Lucciolabella Unit of Pascucci et al. 2006). According to Pascucci et al. (2006), the succession can be subdivided into three intervals (FO_1 to FO_3 in stratigraphic order,
Renieri. Note the coarsening-upward to fining-upward grain-size trends. A marine flooding (marked by a wave-ravinement surface) bounded alluvial deposits at their top. Above this surface lagoon to offshore deposits occur

Fig. 9b). Interval FO_1 ( $280 \mathrm{~m}$ thick) consists of conglomerate and sandstone deposited in an alluvial fan setting (Fig. 9b). The overlying interval FO_2 (115 m thick) records the vertical stacking of at least 15 Gilbert-type delta foresets. Steeply inclined foreset deposits locally alternate with gently-inclined to sub-horizontal sandstone and siltstone (i.e., delta bottomsets). Furthermore, Pascucci et al. (2006) also report the occurrence of some large nested-channelized gravelly deposits, interpretable as topset deposits of the Gilbert-type deltaic system. All these facies display features indicating the deposition in a shallow-marine environment (probably nearshore), including: i) clasts with borings by sponges and by Lithophaga or encrusted with marine barnacles and oysters; and ii) bioturbation in sandstone beds.

Finally, interval FO_3 ( $200 \mathrm{~m}$ thick) is composed of marine fine- to medium-grained shoreface sandstone passing basinward to offshore clay deposits (cf. Lucciolabella Unit of Pascucci et al. 2006) that overlie the FO_2 deposits (Fig. 9B).

\section{Depositional age}

The deposition of these units occurred in the Zanclean. Pascucci et al. (2006) dated these deposits to the MPI2 

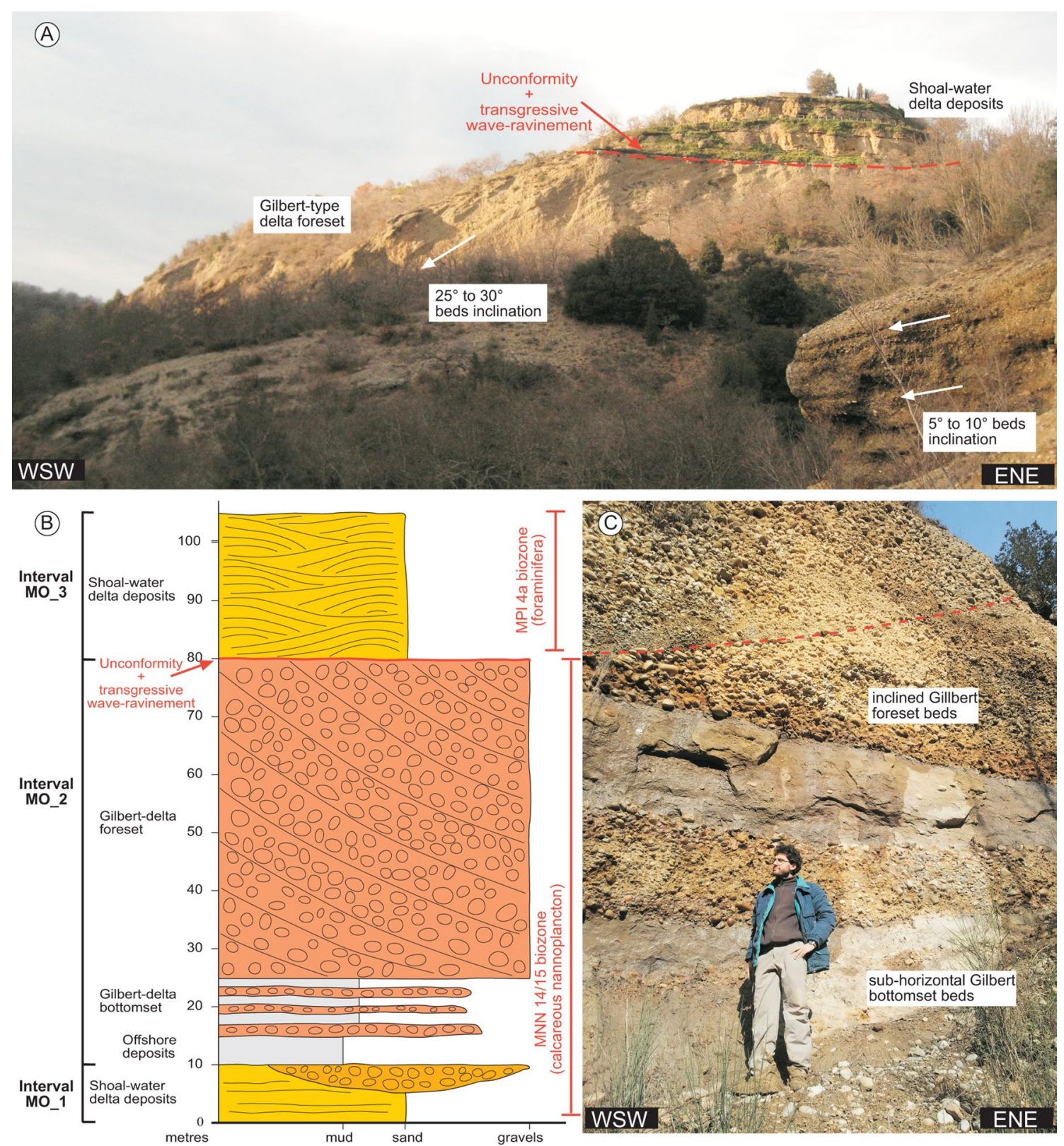

Fig. 8 Sedimentary features of the deposits exposed in the Monticchiello area. a Panoramic view of the upper part of the succession. From the right corner of the picture to the left is possible to observe the steeping of foreset beds, up to the high value that typifies Gilberttype delta foresets. The conglomeratic foresets are abruptly overlaid by shoal-water delta sandstone. b Synthetic stratigraphic log of the investigated succession. c Detail of the bottomset (sub-horizonatal beds) to foreset (steep inclined beds) transition in the lower part of the succession biozone (that starts at $5.08 \mathrm{Ma}$ ), but they do not exclude that sedimentation could have continued up to the MP13 biozone. Bianucci et al. (2009) analysed a section in the FO_2 equivalent Lucciolabella Unit (offshore mudstone) and reported a depositional age comprised between the
MP13 and MP14a biozones. Considering that offshore sediments analysed by Bianucci et al. (2009) are downfaulted with respect to the La Foce succession, we suggest attributing the deposits of the La Foce succession to the MP12-MP13 biozones. 

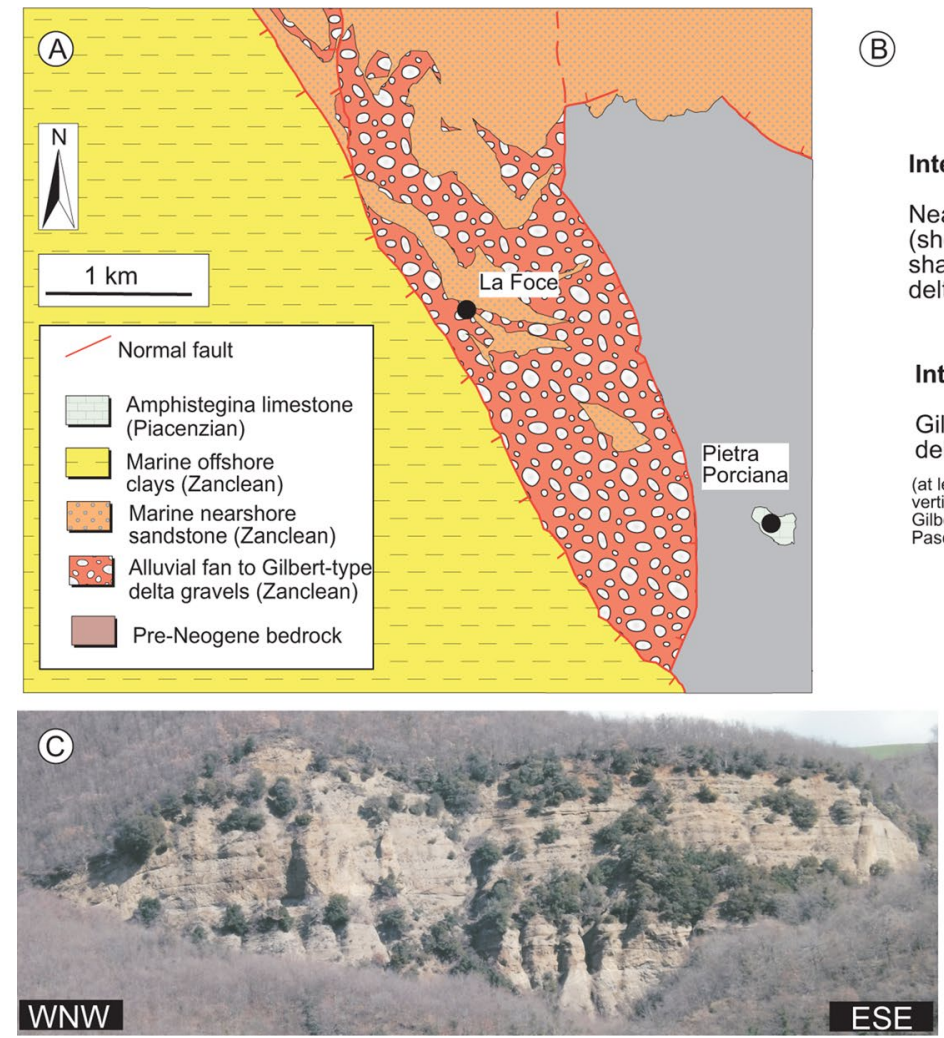

(B)

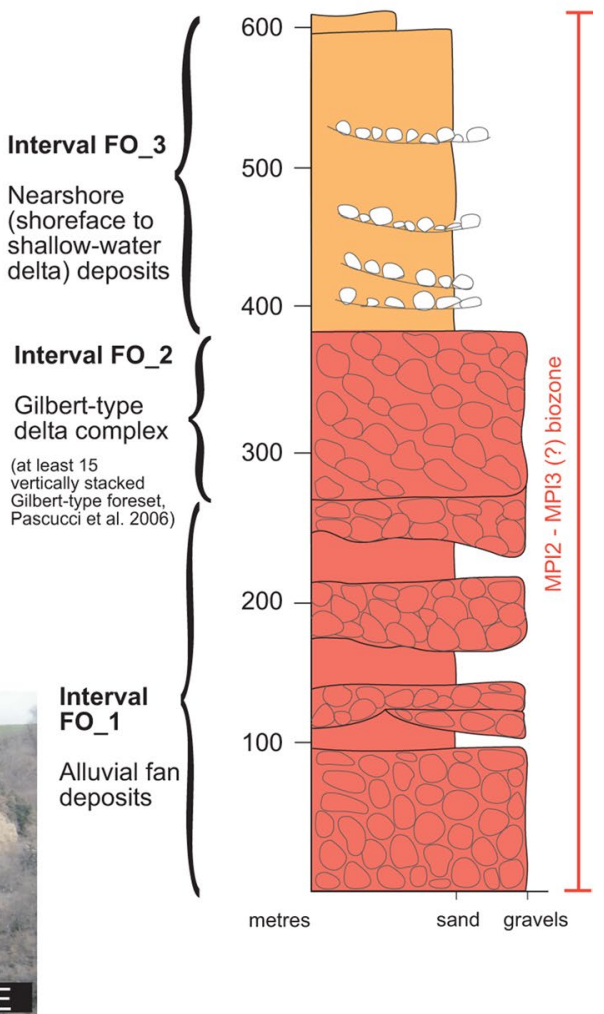

Fig. 9 a Geological map of the "La Foce-Lucciolabella" area (redrawn from Pascucci et al. 2006). b Synthetic sedimentary log of the coarse-grained succession exposed in the surroundings of La Foce (after Pascucci et al. 2006). c Panoramic view of the upper part of the La Foce succession. Note the repeated and vertically stacked Gilberttype delta foresets in interval FO_2

\section{Podere Pantano succession}

\section{Stratigraphy and sedimentology}

The Podere Pantano succession is located in the central part of the Radicofani sub-Basin (Figs. 1, 10a). Here, gravel-dominated bodies occur interstratified within marine mudstone at various stratigraphic positions (c.f. "Conglomerati delle Bandite" of Iaccarino et al. 1994; "Conglomerati di Podere Pantano" of Liotta and Salvatorini 1994; sedimentary unit "P1a" of Pascucci et al. 2006). These deposits are traditionally interpreted as bodies emplaced into offshore mudstone by subaqueous gravity flows.

In this study, we focused on the better exposed and stratigraphically highest of these gravelly bodies (Fig. 10a), which reaches a maximum thickness of about $25 \mathrm{~m}$ and displays a channel-like shape. Its basal surface is erosional and slightly concave upward, while its upper boundary with overlying marine mudstones is sharp and flat. Clasts range from pebble to boulder (up to $30 \mathrm{~cm}$ ) in size, are well-rounded, and show abraded and reworked bio-erosion and Lithophaga traces. These gravel strata generally contain a sand matrix, but also open-framework beds occur. Some clasts show imbrication indicating a northward paleoflow direction. These gravel beds are typically plane- to cross-stratified, a feature that indicates tractional depositional processes. All these sedimentological features in combination with the channel-like shape of the deposits suggest deposition in a fluvial environment, within an incised palaeo-valley.

\section{Depositional age}

The marine mudstone in which the channelized conglomerates are interbedded is attributed to the Zanclean and more specifically to the MP12 biozone (Iaccarino et al. 1994; Liotta and Salvatorini 1994), i.e., the time-interval between 5.08 and $4.52 \mathrm{Ma}$. 

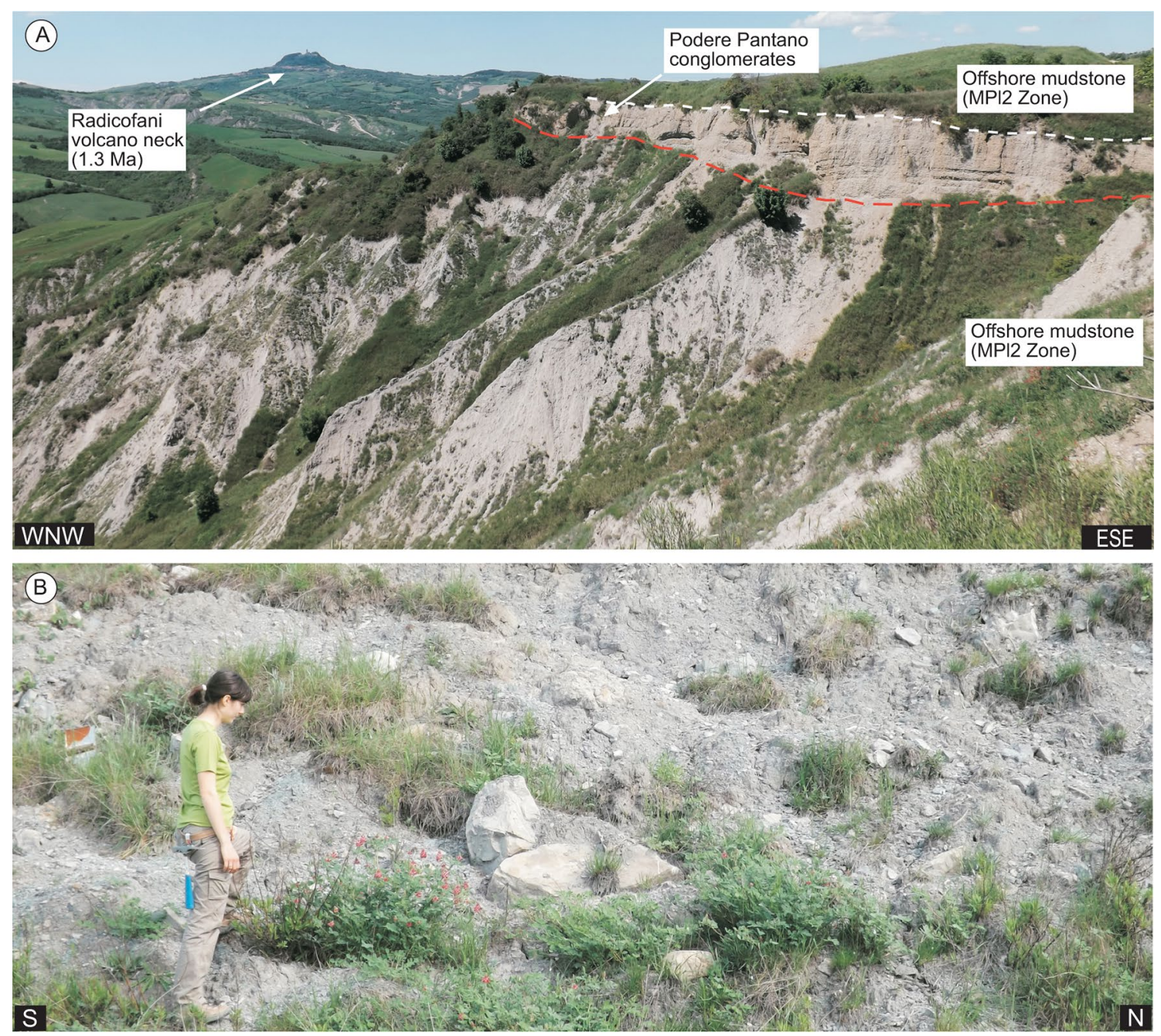

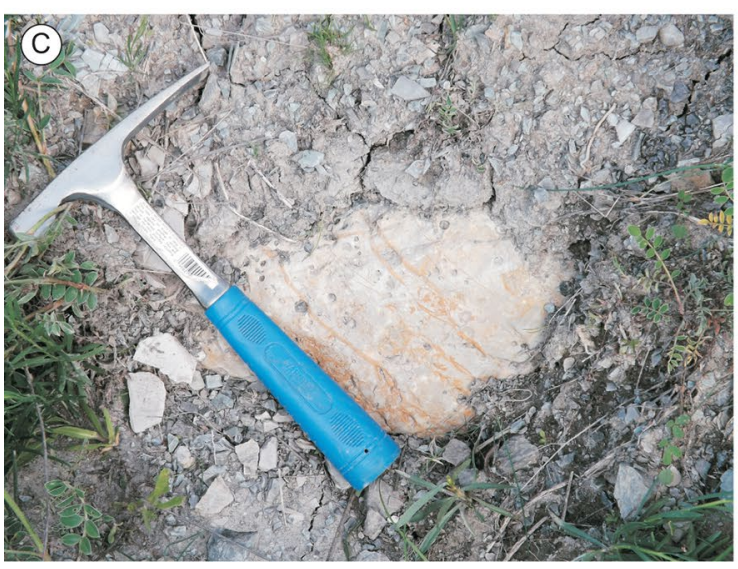

Fig. 10 a View of the Podere Pantano conglomerates (marked by a red dashed line at the base and by a white dashed line at its top), sandwiched between offshore fines dated to the MP12 Zone of Foraminifera zonation. The Radicofani volcano neck (dated at about 1.3 Ma, D'Orazio et al. 1994) is visible in the left corner of the photo. b Outcrop view of typical olistostromes deposits. Note the chaotic

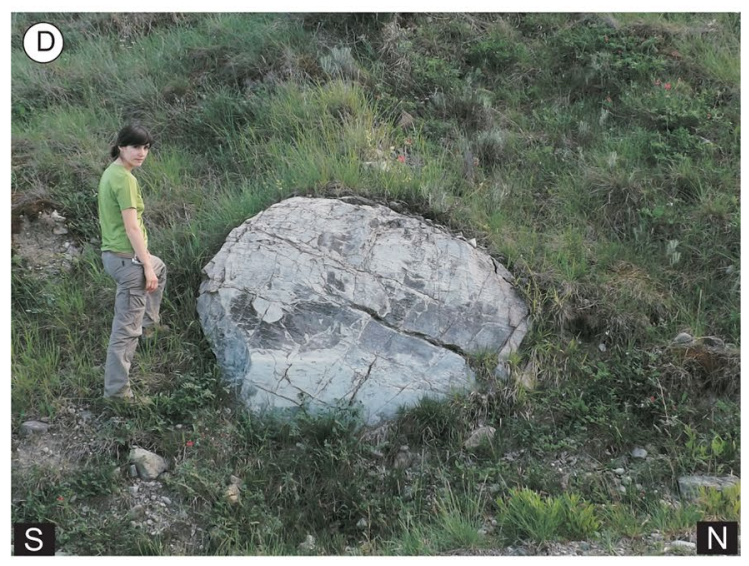

distribution of debris and blocks within the mudstone. Mudstone deposits were deposited in offshore settings during the MP12 biozone. c Olistostrome limestone block perforated by Lithopaga and attesting the re-working of older marine deposits (hammer for scale). d Boulder-sized clasts within olistostrome deposits 


\section{Olistostromes in the south-western margin of the Siena-Radicofani basin}

\section{Stratigraphy and sedimentology}

The south-western margin of the Radicofani sub-Basin is characterized by the occurrence of olistostromes within Pliocene marine deposits (Liotta and Salvatorini 1994). These are slumped chaotic sedimentary bodies emplaced within offshore and deep-water mudstone (Fig. 10b). They are composed of polymictic materials (Figs. 10c, d) derived from Cretaceous Ligurian Units and from re-worked Pliocene deposits (e.g., gravels with bio-erosion traces and borings). Clasts and debris show extreme variability in size (from centimetre-size up to some meters). The origin of the olistostromes is related to the uplift of the western flank of the basin, which triggered slumps of exposed substratum material into the marine basin.

\section{Depositional age}

According to Liotta and Salvatorini (1994), Liotta (1996), Pascucci et al. (2006), olistostrome emplacement took place in the Zanclean during the MPl2 biozone, i.e., between 5.08 and 4.52 Ma.

\section{Discussions}

\section{Evolution of the Siena-Radicofani Basin}

The structural-kinematic and seismic dataset from the Radicofani sub-Basin agrees with the data from the Siena sub-Basin presented by Brogi (2011) (Figs. 1, 3, 4, 5, 6). Similar to the Siena sub-Basin the Pliocene deposits in the Radicofani sub-Basin (S.Un.A in Fig. 3) are also folded in correspondence of the Rapolano-Cetona Fault system, and covered by the youngest sediments showing an overall gentle
Fig. 11 Cartoon showing the evolution of the Siena-Radicofani Basin (modified after Brogi 2020): a late Serravallian- Zanclean (MP11 biozone): sedimentation in a bowl-shaped tectonic depression. Deposition started in the Miocene (continental to brackish/shallow marine? Deposits) and continued in the Zanclean (marine and subordinated continental deposits). b Zanclean (MP12 biozone): activation of HANFs (highangle normal faults) that dissected the previously developed structures and deposits and that locally controlled the variations in accommodation space and sedimenty supply of coarsegrained successions. c Zanclean (MP13 biozone)-Gelasian: marine deposition continued as well as the activity of HANFs, even if with less influence on the sedimentation patterns

\section{A (?) Late Serravallian - Zanclean (MPI1 biozone)}

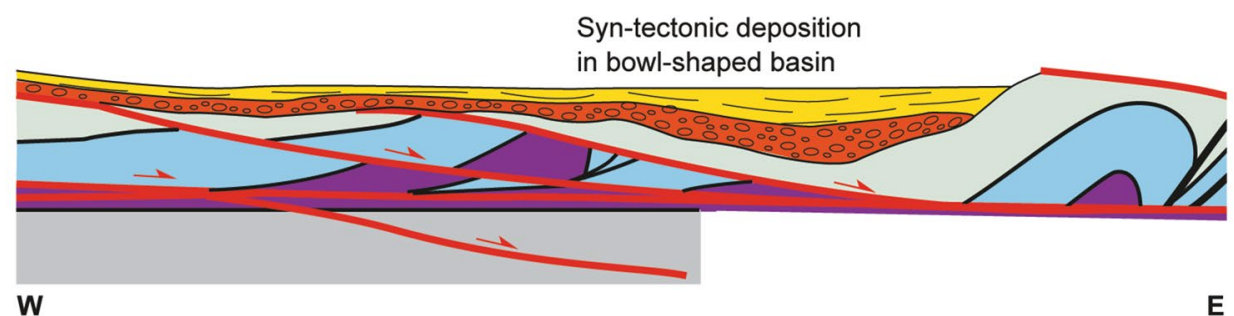

B Zanclean (MPI2 biozone)

Rapolano-Cetona Fault system

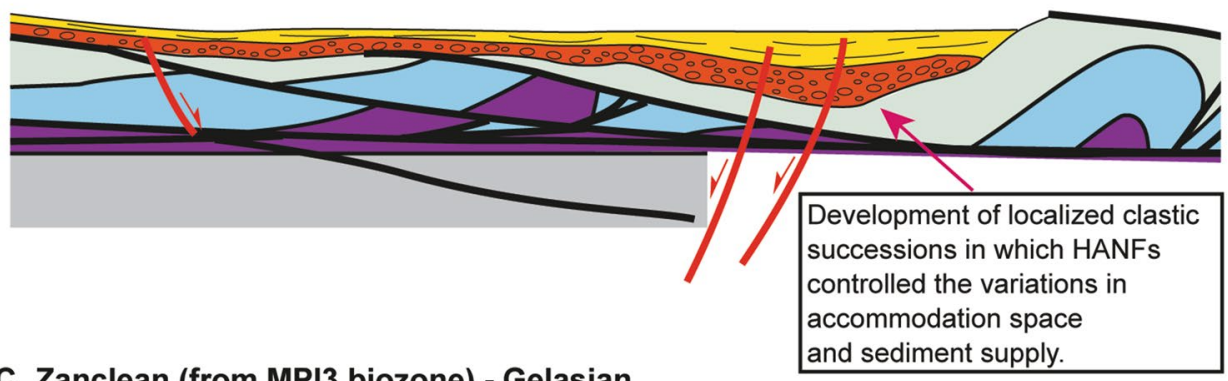

C Zanclean (from MPI3 biozone) - Gelasian

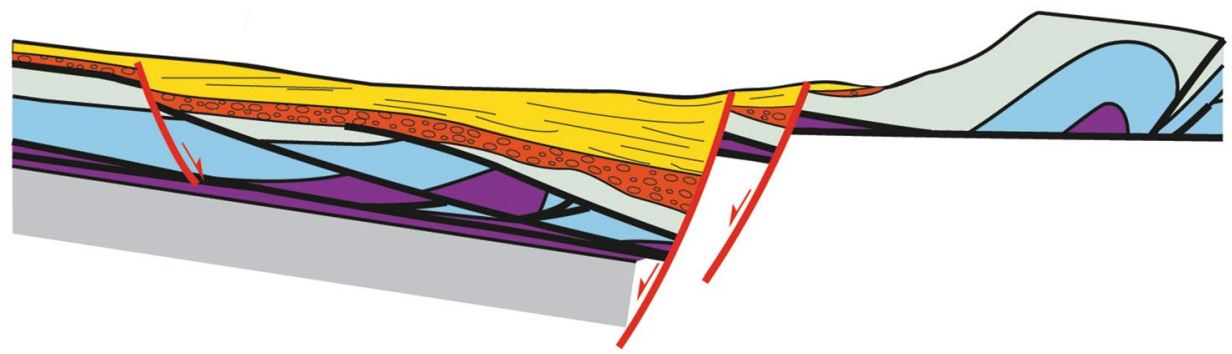

Marine and continental deposits (Pliocene) Continental deposits (Miocene)
Sub-Ligurian and Ligurian Units (Middle Jurassic-Oligocene) Tuscan Succession (Norian-Rhaetian)

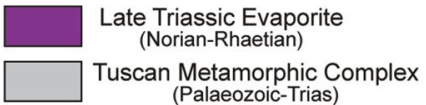


synformal shape well visible on seismic (SIF 13, Fig. 3; Fig. 11). This attests Pliocene syn-sedimentary faulting that ended during the Piacenzian, which is the youngest age of the Pliocene deposits documented in the Radicofani SubBasin (Liotta and Salvatorini, 1994). Similar evidence comes from the other seismic profiles (Fig. 3): the Pliocene activity of the HANFs is, in fact, revealed by the seismic profile SIF11 (Fig. 3). This profile highlights Zanclean sediments onlapping on the basin substratum, which have been rotated and dissected by the Cetona Fault system (Figs. 3, 11). The same fault system is, in turn, buried by Piacenzian sediments (Fig. 3). Miocene sediments did not record syn-depositional faulting associated with Cetona Fault activity. This implies that fault initiation occurred during the Zanclean (Fig. 11). This is in agreement with the data from the Siena sub-Basin, where the activity of the Rapolano Fault system (Fig. 1) has been dated to the same time interval (Bambini et al. 2010; Brogi 2011). In this view, the Miocene deposits imaged at depth in the whole Siena-Radicofani Basin, were accommodated in a bowl-shaped structural depression pre-dating the Cetona Fault and related to previous extensional structures.

The activity of the NE-trending strike- to oblique-slip faults defining the positive and negative flower-like structures (Figs. 3, 5 and 6) is also related to the evolution of the basin. These structures influenced Pliocene sedimentation (Pascucci et al. 2007) and deformed Pliocene sediments, also interrupting the continuity of the NNW-trending Cetona Fault. All evidence supports a contemporaneous interplay between the NNW-SSE striking normal faults (i.e., the Cetona Fault) and the SW-NE striking strike-slip to normal ones. This setting is interpreted as the consequence of the dynamic evolution of the Neogene basins that formed in areas affected by different amounts of extension (cf. Liotta 1991). On the basis of our data and literature (Pascucci et al. 2007; Brogi et al. 2012; Vignaroli et al. 2013), the SW-NE striking faults are likely between Pliocene and late Pleistocene in age or even younger. In fact, these structures played a role in controlling hydrothermal circulation and Pleistocene-Holocene travertine deposition (Brogi et al. 2012, 2020; Vignaroli et al. 2013). Nevertheless, an older age (i.e. middle-late Miocene) cannot be ruled out on the basis of regional considerations, especially when considering observations from areas to the West and Northwest (e,g., Dini et al. 2008; Liotta et al. 2015; Zucchi et al. 2017; Zucchi, 2020). Low-magnitude seismicity aligned along with these structures (Buonasorte et al. 1987; Liotta, 1991; Brogi et al. 2014, 2020; Mantovani et al. 2015; Piccardi et al. 2017) suggests present-day activity, at least along some fault segments.

The coexistence of normal and transfer fault zones has been documented in the whole inner Northern Apennines since the Neogene (Liotta, 1991; Carmignani et al. 1995; Liotta et al. 1998, 2015; Bonciani et al. 2005; Brogi et al.
2005; Zucchi et al. 2017), with magmatism and related hydrothermal circulation related to still on-going extensional processes, with a prominent SW-NE-oriented distribution along the main transfer zones (Liotta and Brogi, 2020). In the Monte Amiata volcano-geothermal area (Brogi 2008; Batini et al. 2003), NE-trending faults are considered to be the main structures controlling the evolution of this middle Pleistocene volcano (Mazzuoli et al. 1995; Ferrari et al. 1996; Cadoux and Pinti, 2009; Brogi et al. 2010a) and the development of $\mathrm{Hg}-\mathrm{Sb}$ ore deposits (Brogi et al. 2011). Similarly, NE-trending structures were strictly associated with the Pleistocene volcanism of Northern Latium (Acocella and Funiciello, 1999, 2006) and magmatism in the northern Tyrrhenian Sea (Dini et al. 2008; Liotta et al. 2015).

\section{Base-level falls: tectonic versus climate}

In this section, we aim to discern the role of tectonics vs climate in controlling the stratigraphic evolution of the investigated sections. Detecting the respective signature of tectonics and climate on the stratigraphic record is generally challenging when assessing successions dominated by paralic and/or continental sediments due to the general paucity of well-defined time constraints. This is also the case in the Neogene basins of the inner Northern Apennines, which could however be compared with coeval and deepwater successions exposed in the outer Northern Apennines, where tectonic and climatic influences on the sedimentation patterns have been well documented (Capozzi and Picotti 2003).

Despite the different Pliocene tectonic settings in the outer and inner Northern Apennines (Conti et al. 2020, and references therein), similar climate conditions can be assumed to have occurred throughout the region. This provides a helpful tool for comparing climatic-driven depositional sequences of the Adriatic side with the stratigraphic record of the SienaRadicofani Basin. In detail, Capozzi and Picotti (2003) recognized four major climate-eustatic events in the Pliocene of the Outer Northern Apennines that directly controlled the stratigraphic record. Of these, only two climate-eustatic sea-level falls took place within the Zanclean (Fig. 12): the older related to a limited glacio-eustatic cooling at about 4.2 Ma (cf. Kloosterboer-van Hoeve et al. 2001), while the younger was related to an important climate cooling phase starting at 3.75 Ma (Vergnaud Grazzini et al. 1999). Consequently, according to Capozzi and Picotti (2003), the basal Pliocene transgression that restored marine settings in the Mediterranean area during the aftermath of the Messinian crisis was followed by a highstand phase that persisted until 4.2 Ma (Fig. 12).

At least two of the investigated successions we investigated documented base-level drops before 4.2 Ma (Fig. 12). In the Podere Renieri succession (Fig. 7) a base-level drop 


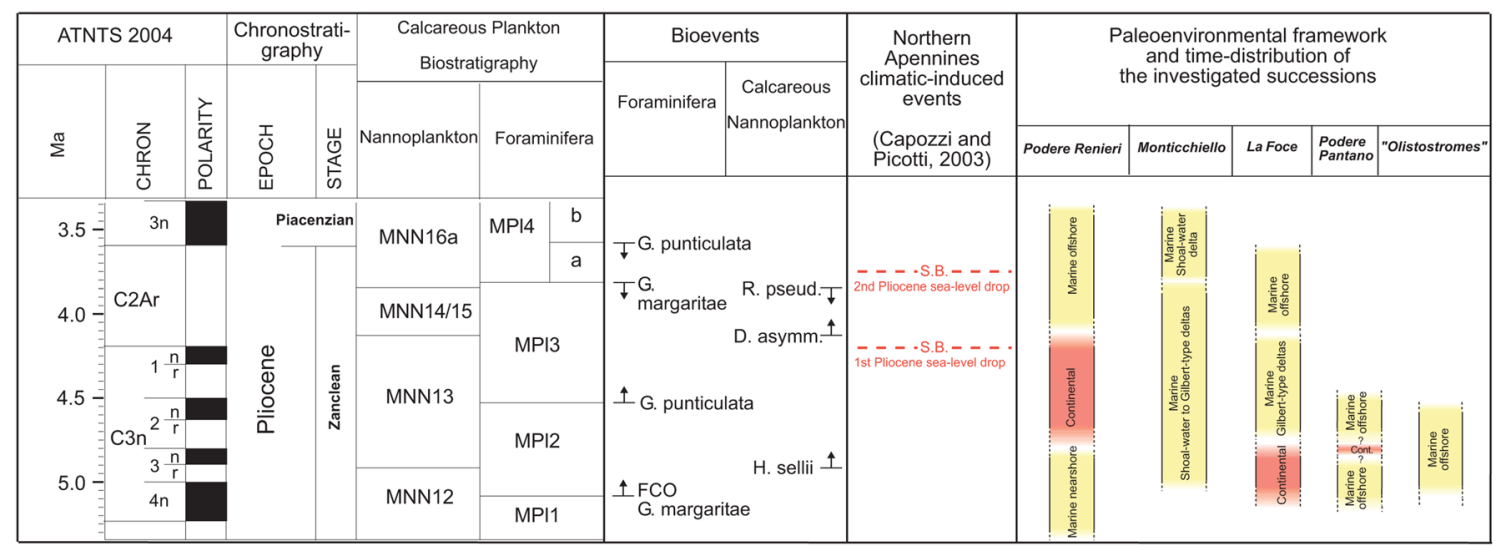

Fig. 12 Estimated bio-chronostratigraphic extent of the investigated sections (white and nuanced intervals indicate uncertain age attribution and/or a possible time-gap of deposition) and comparison with Northern Apennines climate-induced events. Calcareous plankton

within the MPl2 biozone is marked by sharp-based mouth bar deposits above offshore mudstone. Sharp-based mouthbars were also reported as a consequence of autocyclic controlling factors (cf. Fielding et al. 2005; Martini and Sandrelli 2015); but the lack of a complete deltaic succession (prodelta and distributary channel deposits were never recognized) suggests allocyclic factors (i.e., a forced regression) as responsible for this superimposition. Moreover, in the same section the interval PR_2 documents evidence of plinthite-like paleosols (cf. Costantini and Priori 2007), indicating hot and humid conditions. This continental interval is stratigraphically situated between a base-level fall at the base and a transgressive surface at the top and consequently, it records deposition during a lowstand phase of the relative sea-level (Figs. 7, 12). Climate-induced sea-level drops occur during cooling periods, whereas these paleosols document (warming) conditions, suggesting that the relative sea-level fall recorded in this section was not connected to climate.

A base-level fall within the MP12 biozone is also documented in the succession exposed in the Podere Pantano area, as evidenced by the abrupt superimposition of fluvial deposits above fine-grained marine offshore sediments (Fig. 10a). No record exists of base-level falls within the MP12 biozone in successions of the Adriatic side of the Northern Apennines (Capozzi and Picotti 2003), and consequently, such stratigraphic boundaries can be reasonably related to a local uplift phase due to an extensional tectonic pulse. This notion is supported by the coeval occurrence of olistostromes at the south-western margin of the basin (Fig. 10b-d), which was linked to the uplift of the western basin margin (Disperati and Liotta 1998; Acocella 2000).

All these data provide valuable new constraints on the timing of HANF activation in the Siena-Radicofani Basin. bio-magnetostratigraphy derived from the original scheme of Cita (1975), Raffi and Rio (1979), Rio et al. (1990) and Foresi et al. (2001) integrated and chronologically calibrated by Lourens et al. (2004) and Iaccarino et al. (2007)

In fact, basal Zanclean deposits (deposited in the MPl1 biozone) do not show evidence of syn-depositional tectonics, while the recognized tectonically induced base-level drop occurred in the MPI 2 biozone. This suggests that the activation of the HANFs occurred within the MPI2 biozone (i.e., in the time interval between 5.08-4.52 Ma, Fig. 11).

\section{Tectonic control on accommodation space development and sediment supply}

The aim of this section is to discuss the role of tectonics on the development of accommodation space and on the availability of sediments during deposition. Three of the investigated sections provide important elements for reconstructing the relationships between accommodation space and sediment supply:

(i) The alluvial fan system exposed at Podere Renieri (Fig. 7) has been previously interpreted as the consequence of the activation of a local HANF (Bossio et al. 1992; Aldinucci and Sandrelli 2004; Costantini and Priori 2007), that directly controlled the available accommodation space and the amount/type of sediment provided to the alluvial fan system. The continental interval (i.e., interval B, Fig. 7a) shows lacustrine deposits at the base with a poorly defined depositional trend, passing upward to alluvial fan deposits recording a coarsening- to fining-upward vertical trend (Fig. 7a). Fidolini et al. (2013) demonstrated for the Upper Valdarno basin to the NE of the study area, that grain-size trends in fault-sourced alluvial fans provide direct information about syndepositional tectonic activity, suggesting that the 


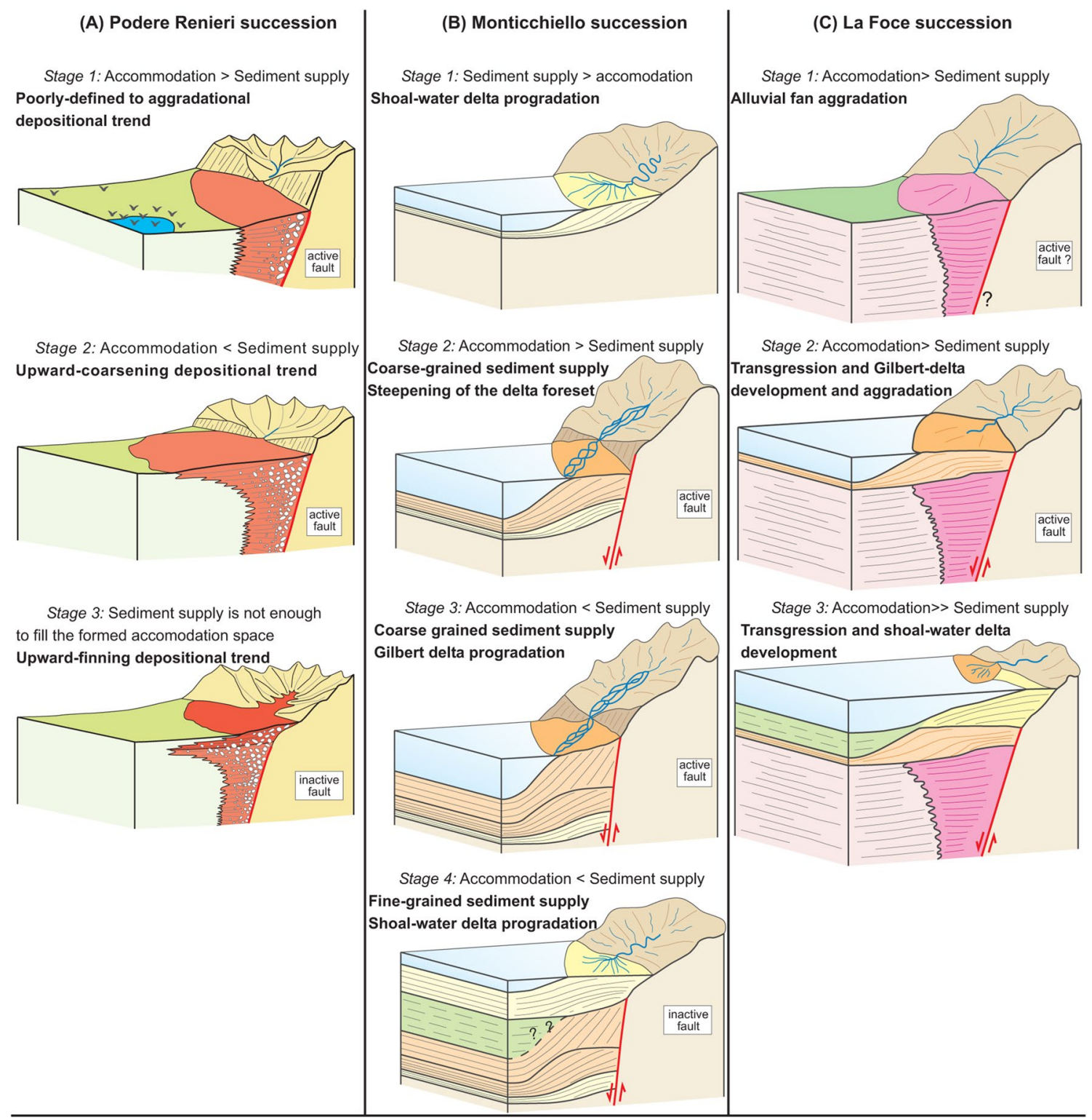

Fig. 13 a Depositional model for the tectonic-influenced alluvial fan deposition of the Podere Renieri section; b Depositional model for the tectonic-influenced deltaic complex exposed in the Monticchiello area; c Depositional model for the tectonic-influenced alluvial to deltaic deposition of the La Foce section. See text for explanation

(ii) The Monticchiello succession (Fig. 8) records the development of at least $65 \mathrm{~m}$ of accommodation space filled by a Gilbert-type delta during a time interval (4.13-3.85 Ma), in which no high-magnitude eustatic variations occurred (Miller et al. 2005, Fig. 11). Consequently, tectonic-induced subsidence is considered as the main driver of accommodation space generation (Fig. 13b). This increase in accommodation space is accompanied by an increase in the average grain size of sediment, which also indicates that tectonic subsidence was the main factor control- 
ling accommodation space generation (cf. Armitage et al. 2011).

Moreover, the overall stratigraphic organization of the Monticchiello succession resembles the organization of typical tectonically controlled deltaic successions reported by Garcìa-Garcìa et al. (2006), in which the transition between different type of deltas, as well as changes in the strata stacking pattern, are strongly related to temporal variations in subsidence rate (i.e., the tectonic controlled accommodation space generation). In detail, Garcìa-Garcìa et al. (2006) document how shoal-water deltas generally develop during periods of decrease in subsidence rates, while Gilbert-type deltas on the other hand develop during periods of increased subsidence rates. Furthermore, according to Garcìa-Garcìa et al. (2006), when a fault becomes inactive and palaeobathymetric relief decreases, a new shoal-water deltaic system could spread over the smoothed seafloor. This tectoniccontrolled stratigraphic setting fits well with the sequence found in the Monticchiello area; therefore we interpret the alternation of shoal-Gilbert-shoal type deltas as the result of tectonic-induced variations in accommodation space and sediment supply.

(iii) The La Foce succession (Fig. 9) records the transition from a continental depositional environment (i.e., an alluvial fan) to a marine shoal-water delta, via a $115 \mathrm{~m}$ thick coarse-grained interval resulting from the vertical stacking of at least 15-20 marine Gilbert-type delta cross-sets (Fig. 9b). This implies that continental sedimentation was interrupted by a marine transgression (Fig. 13c), coeval with the creation of the accommodation space in which the Gilbert-type deltaic systems prograded and aggraded. However, this flooding event was not climatic driven because this time-span was characterized by a substantial sea-level highstand phase in the Mediterranean area (Capozzi and Picotti 2003, Fig. 11). Even if high-frequency and climatic-induced sea-level fluctuations are reported for this time-interval (Miller et al. 2005), the magnitude of such sea-level variations is in the order of $70 \mathrm{~m}$ (ranging from $-48.4 \mathrm{~m}$ to $+21.3 \mathrm{~m}$ and from $-56.4 \mathrm{~m}$ to $+22.1 \mathrm{~m}$ above present sea level during the MP12 Zone and the MPI3 Zone, respectively, Miller et al. 2005). This is not enough to explain the creation of the at least $115 \mathrm{~m}$ of accommodation space, as documented by the sedimentary records. Therefore, we conclude that the creation of accommodation was tectonically driven (Fig. 13C), even if high-frequency climate-induced sea-level fluctuations could have been responsible for the peculiar parasequence-like vertical arrangement of this Gilbert-type delta complex (Fig. 9).
All these sections record an accommodation space generation that cannot be accounted for when only considering climatic factors. Instead, our data point to a dominant tectonic influence on the generation of the available space for sedimentation. Moreover, the Monticchiello and La Foce successions (Figs. 8, 9) record other interesting features that could be considered a signature of active tectonics during deposition. Both successions record coarsegrained Gilbert-type delta sediments deposited just above transgressive surfaces, which lead to the establishment of deeper marine settings. This feature is not compatible with flooding events due to climate change since coarse-grained sediments are generally trapped at river mouths during such transgressive phases, and consequently, the basin is characterized by low and fine-grained sediment supply due to the general sediment starvation (Loutit et al. 1988; Galloway 1989; Martini and Aldinucci, 2017). In contrast, the supply of abundant and coarse-grained sediments during transgressive phases as seen in the Monticchiello and $\mathrm{La}$ Foce successions is only compatible with tectonic-controlled settings, in which the activation of HANFs leads to the contemporaneous local creation of accommodation space (i.e., subsidence) and footwall uplift, in turn causing the rejuvenation of the morphological profile and the high availability of coarse-grained sediments.

\section{Conclusions}

The Siena-Radicofani Basin is a polyphase extensional basin. It originated as a bowl-shaped structural depression during late Serravalian- "early Pliocene" extensional tectonics and was subsequently deformed by HANFs whose activity started in the Zanclean and more specifically during a time interval between 5.08 and $4.52 \mathrm{Ma}$. These HANFs influenced the stratigraphic arrangement of nearby clastic successions (or more generally deposits close to the basin margins) as they locally controlled the variations in accommodation space and sediment supply.

The tectonic-induced signatures are recognizable in the Pliocene marine and continental successions. In marinedominated successions, tectonic influence is expressed by: (i) abrupt facies superimposition indicative of relative sea-level drops that are not coeval with climate and eustatic fluctuations recognized in other nearby basins; and (ii) transgressive settings characterized by high sediment yields, in contrast to sediment starvation as classically expected for climate-induced transgressive phases. Continental successions record tectonic perturbations through: (i) alluvial-fan vertical trends suggesting changes in accommodation/sediment supply ratio during times; and (ii) paleosols testifying climatic settings different from 
those that can be expected applying classical sequence stratigraphic concepts. For example, the occurrence of paleosols documenting hot and humid settings during overall relative sea-level fall is anomalous since such climate-induced sea-level drops should occur during cold phases.

Both marine and continental successions commonly record the creation of accommodation space combined with an increase in sediment supply, while phases during which climatic factors dominate accommodation space generation (i.e., transgressions) are typically characterized by sediment starvation. Even if these "stratigraphic markers" alone are not sufficiently discriminant to support the tectonic control on sedimentation, their synchronous occurrence can be considered indicative for a dominant tectonic control on deposition and can help to better constrain the age of faults in those tectonic settings where detailed time-constraints are lacking.

Acknowledgements The research was funded by the International Association of Sedimentologists (Postgraduate Grant Scheme -2st session 2014, E. Ambrosetti). A. Brogi was supported by FFABR grants (financial support for the base-research activity) from the MIUR (Ministry of Education and University). Giancarlo Molli, Paolo Conti, and the Editor are thanked for their constructive comments, which helped to improve the manuscript.

Funding Open access funding provided by Università degli Studi di Siena within the CRUI-CARE Agreement.

Open Access This article is licensed under a Creative Commons Attribution 4.0 International License, which permits use, sharing, adaptation, distribution and reproduction in any medium or format, as long as you give appropriate credit to the original author(s) and the source, provide a link to the Creative Commons licence, and indicate if changes were made. The images or other third party material in this article are included in the article's Creative Commons licence, unless indicated otherwise in a credit line to the material. If material is not included in the article's Creative Commons licence and your intended use is not permitted by statutory regulation or exceeds the permitted use, you will need to obtain permission directly from the copyright holder. To view a copy of this licence, visit http://creativecommons.org/licenses/by/4.0/.

\section{References}

Acocella V (2000) Space accommodation by roof lifting during pluton emplacement at Amiata (Italy). Terra Nova 12(4):149-155

Acocella V, Funiciello R (1999) The interaction between regional and local tectonics during resurgent doming: the case of the island of Ischia. Italy J Volcanol Geoth Res 88:109-123

Acocella V, Funiciello R (2006) Transverse systems along the extensional Tyrrhenian margin of central Italy and their influence on volcanism. Tectonics 25:003. https://doi.org/10.1029/2005T $\mathrm{C} 00184$

Aldinucci M, Sandrelli F (2004) Geological framework of the Siena Basin. In: International Conference and Field Trip "Paleosols: memory of ancient landscapes and living bodies of present ecosystems" Excursion Guide. Firenze 7-11 giugno, pp 10-15
Aldinucci M, Ghinassi M, Sandrelli F (2007) Climatic and tectonic signature in the fluvial infill of a late Pliocene valley (Siena Basin, Northern Apennines, Italy). J Sediment Res 77:398-414

Ambrosetti E, Martini I, Sandrelli F (2017) Shoal-water deltas in highaccommodation settings: insights from the lacustrine Valimi Formation (Gulf of Corinth, Greece). Sedimentology 64:425-452

Armitage JJ, Duller RA, Whittaker AC, Allen PA (2011) Transformation of tectonic and climatic signals from source to sedimentary archive. Nat Geosci 4(4):231

Arragoni S, Martini I, Sandrelli F (2012) Facies association map of the Pliocene deposits of the central-southern Siena Basin (Tuscany, Italy). J Maps 8(4):406-412

Bambini AM, Brogi A, Cornamusini G, Costantini A, Foresi LM, Lazzarotto A (2010) Geologia dell'area di Rapolano Terme in Provincia di Siena (Appennino Settentrionale). Ital J Geosci 129(3):457-495

Barchi MR (2010) The Neogene-Quaternary evolution of the Northern Apennines: crustal structure, style of deformation and seismicity. J Virtual Explor. https://doi.org/10.3809/jvirtex.2009.00220

Batini F, Brogi A, Lazzarotto A, Liotta D, Pandeli E (2003) Geological features of the Larderello-Travale and Monte Amiata geothermal areas (southern Tuscany, Italy). Episodes 26(3):239-244

Bianchi V, Ghinassi M, Aldinucci M, Boscain N, Martini I, Moscon G, Roner M (2013) Geological map of Pliocene-Pleistocene deposits of the Ambra and Ombrone valleys (Northern Siena Basin, Tuscany, Italy). J Maps 9(4):573-583

Bianucci G, Vaiani SC, Casati S (2009) A new delphinid record (Odontoceti, Cetacea) from the Early Pliocene of Tuscany (Central Italy): systematics and biostratigraphic considerations. Neues Jahrbuch für Geologie und Paläontologie-Abhandlungen 254(3):275-292

Boccaletti M, Sani F (1998) Cover Thrust reactivations related to internal basement involvement during Neogene-Quaternary evolution of the Northern Apennines. Tectonics 17(1):112-130

Bonciani F, Callegari I, Conti P, Cornamusini G, Carmignani L (2005) Neogene post-collisional evolution of the internal Northern Apennines: insights from the upper Fiora and Albegna valleys (Mt. Amiata geothermal area, southern Tuscany). Bollettino della Società Geol Ital 3:103-118

Bonini M (1999) Basement-controlled Neogene polyphase cover thrusting and basin development along the Chianti Mountains ridge (Northern Apennines, Italy). Geol Mag 136(2):133-152

Bonini M, Sani F (2002) Extension and compression in the Northern Apennines (Italy) hinterland: evidence from the late MiocenePliocene Siena-Radicofani Basin and relations with basement structures. Tectonics 21:1-35

Booth-Rea G, Azãnon JM, Garcìa-Duennas V (2004) Extensional tectonics in the northeastern Betics (SE Spain): case study of extension in a multi-layered upper crust with contrasting rheologies. J Struct Geol 26:2039-2058

Bossio A, Cerri R, Costantini A, Gandin A, Lazzarotto A, Magi M, Mazzanti R, Mazzei R, Sagri M, Salvatorini G, Sandrelli F (1992) I Bacini distensivi Neogenici e Quaternari della Toscana. 76a Riunione Estiva SGI-Convegno SIMP, Guida all'escursione B4. Società Geologica Italiana, Rome, pp $198-227$

Bossio A, Costantini A, Lazzarotto A, Liotta D, Mazzanti R, Salvatorini G, Sandrelli F (1993) Rassegna delle conoscenze sulla stratigrafia del Neoautoctono toscano. Memorie della Società Geol Ital 49:17-98

Bossio A, Mazzei R, Salvatorini G, Sandrelli F (2002) Geologia dell' area compresa tra Siena e Poggibonsi ("Bacino del Casino"). Atti Società Toscana di Scienze Naturali Memorie, Serie A 107:69-86

Brogi A (2004) Seismic reflection and borehole logs as tools for tectonic and stratigraphical investigation: new geological data for 
the Tuscan Nappe exposed in the northeastern Mt. Amiata area (Northern Apennines, Italy). Boll Soc Geol It 123:189-199

Brogi A (2008) The structure of the Monte Amiata volcano-geothermal area (Northern Apennines, Italy): Neogene-Quaternary compression versus extension. Int J Earth Sci 97(4):677-703

Brogi A (2011) Bowl-shaped basin related to low-angle detachment during continental extension: The case of the controversial Neogene Siena Basin (central Italy, Northern Apennines). Tectonophysics 499:54-76

Brogi A (2020) Late evolution of the inner Northern Apennines from the structure of the Monti del Chianti-Monte Cetona ridge (Tuscany, Italy). J Struct Geol 141:104205

Brogi A, Fabbrini L (2009) Extensional and strike-slip tectonics across the Monte Amiata-Monte Cetona transect (Northern Apennines, Italy) and seismotectonic implications. Tectonophysics 476:195-209

Brogi A, Liotta D (2008) Highly extended terrains, lateral segmentation of the substratum and basin development: the Middle-Late Miocene Radicondoli Basin (Inner Northern Apennines, Italy). Tectonics 27:5002. https://doi.org/10.1029/2007TC002188

Brogi A, Lazzarotto A, Liotta D, Ranalli G, CROP18 Working Group (2005) Crustal structures in the geothermal areas of southern Tuscany (Italy): insights from the CROP 18 deep seismic reflection lines. J Volcanol Geoth Res 148(1):60-80

Brogi A, Liotta D, Meccheri M, Fabbrini L (2010a) Transtensional shear zones controlling volcanic eruptions: The Middle Pleistocene Mt Amiata volcano (inner Northern Apennines, Italy). Terra Nova 22(2):137-146

Brogi A, Capezzuoli E, Aquè R, Branca M, Voltaggio M (2010b) Studying travertines for neotectonics investigations: middleLate Pleistocene syn-tectonic travertine deposition at Serre di Rapolano (Northern Apennines, Italy). Int J Earth Sci 99(6):1383-1398

Brogi A, Fabbrini L, Liotta D (2011) Sb-Hg ore deposit distribution controlled by brittle structures: the case of the Selvena mining district (Monte Amiata, Tuscany, Italy). Ore Geol Rev 41(1):35-48

Brogi A, Capezzuoli E, Buracchi E, Branca M (2012) Tectonic control on travertine and calcareous tufa deposition in a low-temperature geothermal system (Sarteano, Central Italy). J Geol Soc 169(4):461-476

Brogi A, Capezzuoli E, Martini I, Picozzi M, Sandrelli F (2014) Late Quaternary tectonics in the inner Northern Apennines (Siena Basin, southern Tuscany, Italy) and their seismotectonic implication. J Geodyn 76:25-45

Brogi A, Liotta D, Capezzuoli E, Matera PF, Kele S, Soligo M, Tuccimei P, Ruggieri G, Yu TS, Shen CC, Huntington KW (2020) Travertine deposits constraining transfer zone neotectonics in geothermal areas: an example from the inner Northern apennines (bagno vignoni-val d'orcia area, Italy). Geothermics 85:101763

Buonasorte G, Fiordelisi A, Rossi U (1987) Tectonic structures and geometric setting of the Vulsini Volcanic Complex. Periodico di Mineralogia 56:123-136

Cadoux A, Pinti DL (2009) Hybrid character and pre-eruptive events of Mt Amiata volcano (Italy) inferred from geochronological, petro-geochemical and isotopic data. J Volcanol Geoth Res 179(3-4):169-190

Calcagnile G, Panza GF (1981) The main characteristics of the lithosphere-astenosphere system in Italy and surrounding regions. Pure Appl Geophys 119:865-879

Capozzi R, Picotti V (2003) Pliocene sequence stratigraphy, climatic trends and sapropel formation in the Northern Apennines (Italy). Palaeogeogr Palaeoclimatol Palaeoecol 190:349-371

Carmignani L, Kligfield R (1990) Crustal extension in the Northern Apennines: the transition from compression to extension in the Alpi Apuane core complex. Tectonics 9(6):1275-1303
Carmignani L, Decandia F, Fantozzi PL, Lazzarotto A, Liotta D, Meccheri M (1994) Teriary extensional tectonics in Tuscany (Northern Apennines, Italy). Tectonophysics 238:295-315

Carmignani L, Decandia FA, Disperati L, Fantozzi PL, Lazzarotto A, Liotta D, Oggiano G (1995) Relationships between the Tertiary structural evolution of the Sardinia-Corsica-Provençal Domain and the Northern Apennines. Terra Nova 7(2):128-137

Carmignani L, Decandia FA, Disperati L, Fantozzi PL, Kligfield R, Lazzarotto A, Liotta D, Meccheri M (2001) Inner Northern Apennines. In: Vai GB, Martini PI (eds) Anatomy of an orogen: the Apennines and adjacent Mediterranean basins. Kluwer Academic Publishers

Cita MB (1975) Planktonic foraminiferal biozonation of the Mediterranean Pliocene deep sea record. A revision. Riv Ital Paleontol Stratigr 81:527-544

Collinson JC, Mountney NP, Thompson DB (2006) Sedimentary structures, 3. Terra Publications, Harpenden, p 292

Conti P, Cornamusini G, Carmignani L (2020) An outline of the geology of the Northern Apennines (Italy), with geological map at 1: 250,000 scale. Ital J Geosci 139(2):149-194

Costantini A, Dringoli R (2003) Le rocce raccontano-Nascita del Territorio tra Chianciano e Sarteano. Edited by Amministrazione Provinciale di Siena, pp 63

Costantini EA, Priori S (2007) Pedogenesis of plinthite during early Pliocene in the Mediterranean environment: Case study of a buried paleosol at Podere Renieri, central Italy. CATENA 71(3):425-443

Costantini A, Lazzarotto A, Sandrelli F (1982) Conoscenze Geologico Strutturali. In: Il Graben di Siena. CNR-PFE-RF 9, pp 11-33

D’Orazio M, Laurenzi MA, Villa IM (1991) 40Ar/39Ar dating of a shoshonitic lava flow of the Radicofani volcanic center (Southern Tuscany). Acta Vulcanol 1:63-67

D’Orazio M, Innocenti F, Serri G, Petrini R (1994) Il vulcano di Radicofani nel quadro del magmatismo neogenico-quaternario dell'Appennino Settentrionale. Studi Geol Camerti 1:79-92

Dallmeyer RD, Liotta D (1998) Extension, uplift of rocks and cooling ages in thinned crustal provinces: the Larderello geothermal area (Inner Northern Apennines, Italy). Geol Mag 135:193-202

Davis GH, Coney PJ (1979) Geological development of the Cordilleran metamorphic core complexes. Geology 7:120-124

Davis GA, Lister LS (1988) Detachment faulting in continental extension: perspectives from the southwest U.S. Cordillera. Processes in continental lithospheric deformation. Spec Pap Geol Soc Am 218:133-159

Dini A, Gianelli G, Puxeddu M, Ruggieri G (2005) Origin and evolution of Pliocene-Pleistocene granites from the Larderello geothermal field (Tuscan Magmatic Province Italy). Lithos $81: 1-31$

Dini A, Westerman DS, Innocenti F, Rocchi S (2008) Magma emplacement in a transfer zone: the Miocene mafic Orano dyke swarm of Elba Island, Tuscany, Italy. Geol Soc Lond 302(1):131-148

Disperati L, Liotta D (1998) Estimating uplift of clay-filled extensional basins through the porosity-depth curve: the case of the Radicofani Basin (Italy). Annales Tectonicae 12:162-176

Ferrari L, Conticelli S, Burlamacchi L, Manetti P (1996) Volcanologic evolution of the Monte Amiata, Southern Tuscany: new geological and petrochemical data. Acta Vulcanol 8:41-56

Fidolini F, Ghinassi M, Aldinucci M, Billi P, Boaga J, Deiana R, Brivio L (2013) Fault-sourced alluvial fans and their interaction with axial fluvial drainage: an example from the Plio-Pleistocene Upper Valdarno Basin (Tuscany, Italy). Sed Geol 289:19-39

Fielding CR, Trueman JD, Alexander J (2005) Sharp-based, flood-dominated mouth bar sands from the Burdekin River delta of northeastern Australia: extending the spectrum of mouth-bar facies, geometry, and stacking patterns. J Sediment Res 75(1):55-66 
Finetti IR, Boccaletti M, Bonini M, Del Ben A, Geletti R, Pipan M, Sani F (2001) Crustal section based on CROP seismic data across the North Tyrrhenian-Northern Apennines-Adriatic Sea. Tectonophysics 343(3-4):135-163

Foresi LM, Mazzei R, Salvatorini G (2001) Appendice bio-cronostratigrafica. In: Note Illustrative alla Carta Geologica di S. Maria di Leuca di Bossio A, Mazzei R, Monteforti B, Salvatorini G, Atti della Società Toscana di Scienze, Memorie Serie B 107:145-158

Friedmann SJ, Burbank DW (1995) Rift basins and supradetachment basins: Intracontinental extensional end-members. Basin Res 7(2):109-127

Froitzheim N, Manatschal G (1996) Kinematics of Jurassic rifting, mantle exhumation, and passive-margin formation in the Austroalpine and Penninic nappes (eastern Switzerland). Bull Geol Soc Am 108:1120-1133

Galloway WE (1989) Genetic stratigraphic sequences in basin analysis I: architecture and genesis of flooding-surface bounded depositional units. AAPG Bull 73(2):125-142

García-García F, Fernandez J, Viseras C, Soria JM (2006) Architecture and sedimentary facies evolution in a delta stack controlled by fault growth (Betic Cordillera, southern Spain, late Tortonian). Sed Geol 185(1):79-92

Gawthorpe RL, Leeder MR (2000) Tectono-sedimentary evolution of active extensional basins. Basin Res 12(3-4):195-218

Ghinassi M, Lazzarotto A (2005) Different source areas feeding the Early Pliocene marine Radicofani Basin (Siena): geological and paleogeographical implications. Bollettino della Società Geol Ital 3:15-28

Gibbs AD (1990) Linked fault families in basin formation. J Struct Geol 12:795-803

Gilbert GK (1885) The topographic features of lake shores. US Geol Surv Annu Rep 5:75-123

Harms JC, Southard JB, Spearing DR, Walker RG (1975) Depositional environments as interpreted from Primary Sedimentary Structures and Stratification Sequences. Society of Economic Paleontologists and Mineralogists, Tulsa, p 153

Harms JC, Southard JB, Walker RG (1982) Structures and sequences in clastic rocks SEPM short course no 9, lecture note. Society of Economic Paleontologists and Mineralogists, Tulsa

Iaccarino S, Vernia L, Battini P, Gnappi G (1994) Osservazioni stratigrafiche sul bordo orientale del Bacino di Radicofani (Toscana meridionale). Mem Descr Carta Geol Ital 49:151-168

Iaccarino SM, Premoli Silva I, Biolzi M, Foresi LM, Lirer F, Turco E, Petrizio MR (2007) Practical manual of Neogene Planktonic Foraminifera. International School on Planktonic Foraminifera, $6^{\circ}$ Course - Late Miocene to Holocene. Tipografia Pontefelcino, Perugia

Jolivet L, Daniel JM, Truffert C, Goffe B (1994) Exhumation of deep crustal metamorphic rocks and crustal extension in back-arc regions. Lithos 33:3-30

Jolivet L, Faccenna C, Goffé B, Mattei M, Rossetti F, Brunet C, Storti F, Funiciello R, Cader JP, D’Agostino N, Parra T (1998) Midcrustal shear zones in postorogenic extension: example from the northern Tyrrhenian Sea. J Geophys Res 103(B6):12123-12160

Lazzarotto A, Sandrelli F (1977) Stratigrafia ed assetto tettonico delle formazioni neogeniche del bacino del Casino (Siena). Boll Soc Geol Ital 96:747-762

Liotta D (1991) The Arbia-Val Marecchia Line, Northern Apennines. Eclogae Geol Helv 84(2):413-430

Liotta D (1996) Analisi del settore centro-meridionale del bacino pliocenico di Radicofani (Toscana meridionale). Bollettino della Società Geolog Ital 115(1):115-143

Liotta D, Brogi A (2020) Pliocene-Quaternary fault kinematics in the Larderello geothermal area (Italy): Insights for the interpretation of the present stress field. Geothermics 83:101714
Liotta D, Salvatorini G (1994) Evoluzione sedimentaria e tettonica della parte centro-meridionale del bacino pliocenico di Radicofani. Studi Geologici Camerti Spec 1:65-77

Liotta D, Cernobori L, Nicolich R (1998) Restricted rifting and its coexistence with compressional structures: results from the Crop03 traverse (Northern Apennines Italy). Terra Nova 10:16-20

Liotta D, Brogi A, Meccheri M, Dini A, Bianco C, Ruggieri G (2015) Coexistence of low-angle normal and high-angle strike-to oblique-slip faults during Late Miocene mineralization in eastern Elba Island (Italy). Tectonophysics 660:17-34

Lister GS, Davis GA (1989) The origin of metamorphic core complexes and detachment faults formed during Tertiary continental extension in the northern Colorado River region, USA. J Struct Geol 11:65-94

Lister GS, Banga G, Feenstra A (1984) Metamorphic core complexes of Cordilleran type in the Cyclades. Aegean Sea, Greece. Geology 12:221-225

Locardi E, Nicolich R (1992) Geodinamica del Tirreno e dell'Appennino centro-meridionale: la nuova carta della Moho. Mem Soc Geol It 41:121-140

Lourens LJ, Hilgen FJ, Laskar J, Shackleton NJ, Wilson D (2004) The Neogene period. In: Gradstein FM, Ogg JG, Smith AG (eds) A geologic time scale 2004. Cambridge University Press, Cambridge, pp 409-440

Loutit TS, Hardenbol J, Vail PR, Baum GR (1988) Condensed sections: the key to age determination and correlation of continental margin sequences. Sea-level changes: an integrated approach. SEPM Special Publication, London, pp 183-213

Mack GH, William Seagern R, Mike R, Leeder W (2003) Synclinal horst basins: Examples from the southern Rio Grande rift and southern transition zone of southwestern New Mexico USA. Basin Res 15:365-377

Mantovani E, Viti M, Babbucci D, Tamburelli C, Cenni N, Baglione M, D'Intinosante V (2015) Present tectonic setting and spatiotemporal distribution of seismicity in the Apennine belt. Int $\mathbf{J}$ Geosci 6:429-454

Mariani M, Prato R (1988) I bacini neogenici costieri del margine tirrenico: approccio sismo-stratigrafico. Mem Soc Geol Ital 41:519-531

Marinelli G (1975) Magma evolution in Italy. In: Squyres CH (ed) Geology of Italy. The Earth sc Soceity of the Libyan Arab Repubblic, Tripoli, pp 165-219

Marini L (2001) Stratigrafia delle Formazioni Plioceniche nell'area a Nord di Pienza (Siena). Master Degree Thesis, University of Siena, pp 86

Marroni M, Moratti G, Costantini A, Conticelli S, Benvenuti MG, Pandolfi L, Bonini M, Cornamusini G, Laurenzi MA (2015) Geology of the Monte Amiata region, Southern Tuscany Central Italy. Ital J Geosci 134(2):171-199

Martini I, Aldinucci M (2017) Sedimentation and basin-fill history of the Pliocene succession exposed in the northern Siena-Radicofani Basin (Tuscany, Italy): a sequence-stratigraphic approach. Riv Ital Paleontol Stratigr 123(3):407-432

Martini IP, Sagri M (1993) Tectono-sedimentary characteristics of Late Miocene-Quaternary extensional basins of the Northern Apennines. Italy Earth-Sci Rev 34(3):197-233

Martini I, Sandrelli F (2015) Facies analysis of a Pliocene river-dominated deltaic succession (Siena Basin, Italy): implications for the formation and infilling of terminal distributary channels. Sedimentology 62(1):234-265

Martini I, Aldinucci M, Foresi LM, Mazzei R, Sandrelli F (2011) Geological map of the Pliocene succession of the Northern Siena Basin (Tuscany, Italy). J Maps 2011:193-205

Martini I, Arragoni S, Aldinucci M, Foresi LM, Bambini AM, Sandrelli F (2013) Detection of detached forced-regressive nearshore 
wedges: a case study from the central-southern Siena Basin (Northern Apennines, Italy). Int J Earth Sci 102(5):1467-1489

Martini I, Foresi LM, Bambini AM, Riforgiato F, Ambrosetti E, Sandrelli F (2016) Calcareous plankton bio-chronostratigraphy and sedimentology of the "I Sodi" section (Siena Basin, Italy): a key section for the uppermost Neogene marine deposition in the inner northern Apennines. Ital Journal of Geosci 35(3):540-547

Martini I, Ambrosetti E, Sandrelli F (2017) The role of sediment supply in large-scale stratigraphic architecture of ancient Gilberttype deltas (Pliocene Siena-Radicofani Basin, Italy). Sed Geol 350:23-41

Martins-Neto MA, Catuneanu O (2010) Rift sequence stratigraphy. Mar Pet Geol 27(1):247-253

Mazzuoli R, Tortorici L, Ventura G (1995) Oblique rifting in Salina, Lipari and Vulcano islands (Aeolian islands, southern Italy). Terra Nova 7:444-452

McKenzie DP (1978) Some remarks on the development of sedimentary basins. Earth Planet Sci Lett 40:15-32

Miller KG, Kominiz MA, Browninf JV, Wright JD, Mountain GS, Katz ME, Pekar SF (2005) The Phanerozoic record of global sea-level change. Science 310(5752):1293-1298

Pascucci V (2004) Radicofani Basin. In: Sagri M, Martini IP, Pascucci V (eds) 32nd International Geological Conference, Florence, Italy, 20-28 Agosto 2004: Field trip guide book, P15, pp 20-21

Pascucci V, Merlini S, Martini IP (1999) Seismic stratigraphy of the Miocene-Pleistocene sedimentary basins of the Northern Tyrrhenian Sea and western Tuscany (Italy). Basin Res 11(4):337-356

Pascucci V, Costantini A, Martini IP, Dringoli R (2006) Tectonosedimentary analysis of a complex, extensional, Neogene basin formed on thrust-faulted, Northern Apennines hinterland: Radicofani Basin. Italy Sediment Geol 183(1):71-97

Pascucci V, Martini IP, Sagri M, Sandrelli F (2007) Effects of transverse structural lineaments on the Neogene-Quaternary basins of Tuscany (inner Northern Apennines, Italy). In: Nichols G, Williams E, Paola C (eds) Sedimentary processes, environments and basins: a tribute to Peter Friend. International Association of Sedimentologists, Special Publication, vol 38, Pp 155-182

Passerini P (1964) Il Monte Cetona (Provincia di Siena). Boll Soc Geol It 83:219-238

Peccerillo A (2003) Plio-quaternary magmatism in Italy. Episodes 26(3):222-226

Piccardi L, Vittori E, Blumetti AM, Comerci V, Di Manna P, Guerrieri L, Baglione V, D'Intinosante V (2017) Mapping capable faulting hazard in a moderate-seismicity, high heat-flow environment: the Tuscia province (southern Tuscany-northern Latium, Italy). Quatern Int 451:11-36
Poli G, Peccerillo A, Donati C (2002) Genesis of Miocene-Quaternary acid rocks form the Tuscan Magmatism Province: some implications for structure of the Apennine lithosphere. Boll Soc Geol Ital Spec 1:129-140

Raffi I, Rio D (1979) Calcareous nannofossil biostratigraphy of DSDP site 143 - Leg 13 (Tyrrhenian Sea-western Mediterranean). Riv Ital Paleontol Stratigr 85:127-172

Riforgiato F, Foresi LM, Mazzei R, Salvatorini G, Sandrelli F (2005) Chronostratigraphic revision of some Pliocene basins in Tuscany at the Zanclean/Piacenzian boundary. Bollettino della Società Geologica Italiana Suppl 3:7-13

Rio D, Raffi I, Villa G (1990) Pliocene-Pleistocene Calcareous Nannofossils distribution patterns in the western Mediterraean. In: Kasten K, Mascle J (eds) Proceeding ODP Scientific Results. Ocean Drilling Program, College Station, pp 513-533

Rosenbaum G, Regenauer-Lieb K, Winberg R (2005) Continental extension: from core complexes to rigid block faulting. Geology 33(7):609-612

Serri G, Innocenti F, Manetti P (1993) Geochemical and petrological evidence of the subduction of delaminated Adriatic continental lithosphere in the genesis of the Neogene-Quaternary magmatism of central Italy. Tectonophysics 223:117-214

van Kloosterboer HML, Steenbrink J, Brinkhuis H (2001) A shortterm cooling event, 4.205 million years ago, in the Ptolemais Basin, northern Greece. Palaeogeogr Palaeoclimatol Palaeoecol 173(1):61-73

Vergnaud Grazzini C, Capotondi L, Lourens L (1999) Comparative regional charts of Pliocene events. In: Wrenn JH, Suc JP, Leroy SAG (eds) The Pliocene: time of change. American Association of Stratigraphic Palynologists, London, pp 13-47

Vignaroli G, Pinton A, De Benedetti AA, Giordano G, Rossetti F, Soligo M, Berardi G (2013) Structural compartmentalisation of a geothermal system, the Torre Alfina field (central Italy). Tectonophysics 608:482-498

Wernike B, Burchfiel BC (1982) Modes of extension tectonics. J Struct Geol 4:105-115

Zucchi M (2020) Faults controlling geothermal fluid flow in low permeability rock volumes: An example from the exhumed geothermal system of eastern Elba Island (northern Tyrrhenian Sea, Italy). Geothermics 85:101765

Zucchi M, Brogi A, Liotta D, Rimondi V, Ruggieri G, Montegrossi G, Caggianelli A, Dini A (2017) Permeability and hydraulic conductivity of faulted micaschist in the eastern Elba Island exhumed geothermal system (Tyrrhenian sea, Italy): insights from Cala Stagnone. Geothermics 70:125-145 